\title{
Parvulus Puer in Annuntiatione Virginis Un estudio sobre la iconografía de la Encarnación
}

\author{
JuLIO I. GonZÁLEZ MontañÉS
}

\begin{abstract}
Reprehensibiles, inquit, sunt etiam Pictores, cum pingunt, in Annunciationis parvulum Puerum formatum, scilicet lesum mitti in uterum Virginis, quasi non esset de sunstantiam Virginis corpus ejus assumptum.
\end{abstract}

San Antonio de Florencia, Summa Theologica, III, tit. 8, 4, II

El tema de la Anunciación es, sin duda, uno de los más representados en el arte cristiano. Desde su aparición en las catacumbas del siglo Iv ha ocupado un lugar preferente en todas las épocas, en todos los lugares y en todos los campos de la actividad artística, sólo las Natividades y Adoraciones de los Magos pueden, en períodos como el medieval, competir con las Anunciaciones en frecuencia de aparición. Razones de índole teológica y artística permiten explicar el éxito del tema a lo largo de los siglos.

La Anunciación no es simplemente un episodio de la leyenda de la Virgen, con ella llega la "plenitud de los tiempos» (Gal. 4, 4), es el momento culminante de la vida de María pero también el comienzo de la misión de Cristo en la tierra ya que, desde el mismo momento en que María da su asentimiento a las palabras del Ángel, la Encarnación se materializa

* El texto del presente artículo fue presentado como trabajo de investigación en los cursos de doctorado del Departamento de Historia del Arte de la UNED (Octubre de 1995). He mantenido la redacción original aunque suprimiendo, por razones de espacio, los índices y el catálogo que incluye la descripción, comentario y bibliografía de 127 ejemplares, la mayoría de procedencia italiana (35) y germánica (35), seguidos por los hispanos (23), flamencos (12), franceses (11) e ingleses (10) además de una obra de procedencia desconocida; pueden consultarse los mismos en el original depositado en el Departamento de Historia del Arte de la mencionada Universidad. Los números de catálogo que aparecen citados en las notas se entienden referidos al mencionado trabajo. 
y tiene lugar la concepción virginal, «Et verbum caro factum est». Anunciación y Encarnación no son, en el fondo, más que un mismo acontecimiento cuya finalidad, la redención del hombre, se cumple por medio del sacrificio de Cristo en la cruz. Así pues, el tema admite una triple interpretación, cristológica, mariana y angélica, lo que hace su presencia prácticamente ineludible en cualquier ciclo dedicado a Cristo o a María y permite utilizarlo como imagen aislada de devoción ?.

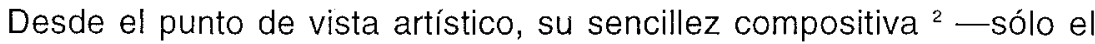
ángel y María son imprescindibles-, lo convierte en un tema adecuado para su utilización en puertas, arcos triunfales, o alas de retablo, al tiempo que su carácter intimista le hace también apropiado para las imágenes de devoción privadas por 10 que no suele faltar en los abundantísimos Breviarios y Libros de Horas.

El episodio aparece narrado escuetamente sólo en uno de los evangelios canónicos (Luc. 1, 26-38) pero la imaginación de los apócrifos, y de la literatura posterior inspirada por ellos ${ }^{3}$, suplió las carencias del relato ca-

Al menos desde el siglo $v$ en oriente y desde el vi en Roma se celebraba 25 de marzo la fiesta de la Anunciación. El culto, extendido por ordenes religiosas como los Servites o los franciscanos llevó, sobre todo en Italia, a la consagración de templos dedicados al acontecimiento (las annunuziatas) y al culto de la Virgen de la Buena Nueva o de la Expectación. Incluso la Anunciación se convirtió en fiesta patronal para algunos gremios como los ceramistas (por el jarrón de mayólica con lirios que suele aparecer en la escena) (Vid. Reau (1955-59), II, II, págs. 174-75). (sobre el origen del culto, la inclusión de la fiesta en los calendarios litúrgicos y las razones que llevaron a establecer la fecha del 25 de marzo véase CABROL y LECLERQ (1926), l, cols. 2241 ss., y BENEDICTO XIV, De Festis Domine nostri Jesu Christi Et Beatae Mariae Virginis. Opera, vol. X, Lib. II cap. III De festo Sanctissimae Annunciationis. Die 25. Marti, Roma, Imp. Palearini, 1751, págs. 443 ss.

2 Sin embargo, existe siempre una disimetría provocada por la desigual importancia y dinamismo de los personajes (REAU (1955), II, II, pág. 177) que suele resolverse situando a María y al ángel en espacios diferentes y, en muchos casos, creando en realidad dos escenas distintas, cada una con su propio orden interno. Tai disposición ha sido interpretada como una alusión a que la presencia del ángel ante María se concibiese de una manera más espiritual o mental que física (GARCía IGLESIAS (1986), págs. 28 y ss.). Sin embargo, la tradición patrística (S. Jerónimo) y la teología occidental (desde S. Bernardo a Alastruey o Carol, pasando por Sto. Tomás o Ludolfo de Sajonia) mantienen explícitamente lo contrario por lo que creo que son únicamente razones compositivas las que explican la popularidad del modelo. Tan sólo entre los teólogos orientales se mantiene la tesis de la presencia espiritual (por ejemplo, en el Oficio bizantino de la Vigilia se afirma: «El ángel fue enviado del cielo[...]. El servidor incorporal fue enviado a la ciudad en forma espiritual para dar a conocer el descenso y el advenimiento del Salvador". Vid. FourneE (1968), pág. 229).

3 Fundamentalmente el Protoevangelio de Santiago y el Libro de la Natividad de María.. También aportan novedades el Evangelio del Pseudo Mateo y el Evangelio armenio de la Infancia, aunque su influencia se circunscribe casi totalmente al mundo bizantino. (Vid. la edición bilingüe de SANTOS OTERO (1975). Son numerosísimos los textos inspirados en el relato de los apócrifos. Por su influencia en el arte merecen destacarse el Speculum Historiae de Vicente de Beauvais, la Leyenda Aurea de Jacobo de Vorágine y, algo más tarde, las Meditationes vitae Christi (atribuidas a S. Buenaventura) y la Vita Christi de Ludolfo de Sajonia. 
nónico aportando una serie de datos sobre las circunstancias en las que habría tenido lugar el acontecimiento (María estaba en su casa entregada a la oración, leyendo arrodillada o hilando la púrpura para el velo del templo... etc.) que pronto tuvieron reflejo en el arte.

En el terreno iconográfico, se han señalado dos variantes principales ${ }^{4}$ : una fórmula de origen griego ${ }^{5}$ en la que María aparece sentada y otra, siria, en la que la Virgen se levanta ante la presencia del mensajero celestial. A estos dos tipos principales cabría añadir dos más. Un tercero, en el que María aparece arrodillada tal y como se la describe en el apócrifo del Pseudo-Mateo ${ }^{6}$ y un cuarto en el que es el ángel el que se arrodilla ${ }^{7}$. Al núcleo básico de la escena - María y el ángel- pueden añadírsele otros personajes: unos más frecuentes, como el Espíritu Santo en forma de paloma ${ }^{8}$

4 MÂle (1922) cap. II, apd. IV, y (1952), pág. 16.

3 La fórmula es helenistica y, como en otros aspectos de la iconografía del tema —el ángel, por ejemplo, adopta los atributos de Mercurio, el mensajero de los dioses-, pueden rastrearse influencias de representaciones clásicas como las del mito de Danae. (Vid. Mateo Gómez (1993), pág. 39).

6 El tipo aparece en algunos ejemplos de los ss. $v$ y vi en el Norte de Italia y Sur de Francia (RosB (1936), pág. 481). A partir del siglo xilı se hará muy frecuente como recurso para enfatizar la humildad de María. Así la representa Giotto en la Capilla de la Arena de Padua, y así se la describe en las Meditationes Vicae Christi. (cap. IV, pág. 17. Cito por la edición castellana de 1893, traducción de la romana de 1588, Madrid, Imp. de Gregorio del Amo).

7 De rodillas ante su señora es como se lo figura el autor de las Meditationes, y es probable que en la difusión del modelo haya colaborado la popularidad del relato franciscano. Sin embargo, en el arte el ángel arrodillado aparece ya en el siglo xII (Relieve de la Anunciación del claustro de Silos y tímpano de Gredilla de Sedano (Burgos) y su origen quizá haya que buscarlo en la costumbre feudal de arrodillarse ante el señor como gesto de sumisión que aparece reflejada en el clisé trovadoresco del caballero rodilla en tierra ante la amada.

${ }^{8}$ En ocasiones aparece situada sobre la cabeza de la Virgen, haciendo visibles las palabras del Evangelio "El Espíritu Santo vendrá sobre ti, y la virtud del altísimo te cubrirá con su sombra» (Lc. I, 35), aunque es más frecuente representarla descendiendo hacia la oreja de Maria en referencia a la doctrina de la conceptio per aureri planteada en los apócrifos (Evangelio armenio de la infancia, V, 9) y adoptada por buena parte de la tradición patrística desde el siglo IV. El Verbo habría penetrado en María a través de la oreja, al mismo tiempo que el mensaje del ángel. Esta doctrina, aunque minoritaria frente a los defensores de la conceptio per uterum, mantuvo su vigencia a lo largo de los siglos interpretada en un sentido no estrictamente material; en virtud de la fe (conceptio per fidem), la concepción tuvo lugar en el intelecto de María antes de tener físicamente a Jesús en su seno ( «aquel que é contigo na mente, seja contigo no ventre» dice la versión portuguesa de la Vita Christi de Ludolfo de Sajonia, cap. V, $\mathrm{n}^{\mathbf{0}}$ 166). Tal concepción «por la oreja» se vería ademas apoyada por la existencia de un antetipo en las palabras del Salmo 45, 11: "Oye, hija, y mira; inclina tu oido:/ olvida tu pueblo y la casa de tu padre", además de aparecer prefigurada por antítesis en el episodio de Eva y la Serpiente. Del mismo modo que el demonio, a través de la persuasión, hablando a la oreja de Eva, introdujo el pecado en el mundo, también a través de la oreja entró Jesús en María, la nueva Eva que borra el pecado de su antecesora (sobre la asociación Eva/María vid. infra nota 70) para el tema de Eva con la Serpiente véase el texto de S. Zenon de Verona en GuLdan (1968), pág. 158). Son numerosos los textos en los que se hace referencia a la conceptio per aurem pero quizá los más conocidos sean los versos atribuidos a Santo Tomas Becket: 
- Dios Padre ${ }^{9}$-solo o rodeado de coros angélicos ${ }^{10}$-, otros poco habituales como la "escolta de honor» que acompaña en ocasiones a Gabriel ", - la sirvienta de María que aparece hilando la púrpura con su señora ${ }^{12}$.

Por lo que respecta a la ambientación de la escena, pueden señalarse tres variantes principales: la más antigua, fiel al relato evangélico, sitúa a los personajes en un exterior con un fondo de arquitecturas que aluden a la ciudad de Nazaret. Es la solución más frecuente en el arte paleocristiano y bizantino que dará lugar más tarde en Italia a la ambientación de pórtico, muy popular en el Quattrocento.

Otra posibilidad consiste en situar el acontecimiento en un interior doméstico, suponiendo, como los apócrifos, que la Salutación se habría producido en la casa de María. Esta solución es la habitual en el arte flamenco desde el siglo XIV.

El tercer tipo, frecuente en el arte francés, presenta la escena en el interior de un templo. La iglesia es un símbolo de María - San Bernardo en sus homi-

\section{Gaude, Virgo, mater Christi}

Quae per aurem concepisti!

También en el mundo animal encuentran los teólogos medievales paralelos para semejante concepción, por ejemplo en la comadreja a la que la mayoría de los Bestiarios atribuyen la cualidad de soncebir por la oreja y parir por la boca.

- Frecuente en la época bajomedieval, suele representársele revestido con atributos pontificales - tiara- e imperiales - cetro, bola-, que simbolizan el poder de Dios a través de su Encarnación en las máximas autoridades temporal y espiritual. La iconografía tiene probablemente su origen en el teatro religioso ya que asi era como aparecian caracterizados los actores que representaban el papel de Dios en los Misterios (Vid. Mâle (1952), pág. 91 y ReAu (1955-59), II, I, pág. 8).

10 La presencia de las "huestes angélicas" en la Anunciación se documenta en el arte desde principios del $S$. $x v$ aunque las representaciones se basan en una tradición textual muy anterior. Ya en el S. v el apócrifo siriaco Historia de la Santa Virgen María se refiere a ellas y se conserva un nutrido grupo de himnos de los siglos xli1-Xv que abundan en el mismo tema, al igual que las Meditationes Vitae Christi, o la Vita Christi de Ludolfo de Sajonia. Sobre el origen del motivo véase MÂLE (1952), págs. 239 ss. y el apéndice que incluye DenNy (1977) The Annunciation with Many Angels, págs. 148-160.

"La presencia de la "escolta" es poco frecuente antes hasta finales del xvi pero pueden senalarse varios casos (Vid. MORALEJo (1977), pág. 195 para los ejemplos anteriores al siglo XIII, y REAU (1955-59), II, I, pág. 181 para los posteriores). Isabel de Villena en su Vita Christi habla de la presencia de dos ángeles $y$, para los casos en que aparecen tres, cabe pensar en una reminiscencia del tema bizantino de la Filogenia de Abraham al cual tres ángeles anunciaron el nacimiento de Isaac (Cf. Les Trois Pélerinages de Guillaume Degulleville, Bib. Sainte-Geneviève de París, ms. 1130, fol. 166v, en Rовв (1936), f. 46). Se ha apuntado también la posibilidad de que en algunos casos en los que aparecen dos ángeles -uno de ellos descendiendo en picado hacia María-, el ángel volador no sea tal sino una representación del Logos (GössmanN (1957)).

12 La representación de Maria hilando la púrpura para el velo del templo se inspira en los apócritos (Protoevangelio de Santiago, $\mathrm{XI}, 1$ ) siendo bastante frecuente en arte bizantino y también, aunque menos, en el occidental. Más rara es la presencia de la sivienta, sobre todo en occidente, pero hay algunos casos (véase, en el catálogo, la Anunciación de St. Angelo de Ravescanina, cat. $\mathrm{n}^{\circ}$ 12). 
lías compara a la Virgen con un templo-, pero también una referencia a la basílica de la Anunciación, levantada por Santa Elena sobre la casa en la que según la tradición había tenido lugar la Salutación Angélica ${ }^{13}$. Existen otras posibilidades, inspiradas en los apócrifos ${ }^{14}$, como situar la escena al lado de un pozo o fuente pero este tipo de Anunciaciones son extremadamente raras en occidente, aunque tuvieron cierto éxito en el arte paleocristiano ${ }^{15} \mathrm{y}$ bizantino ${ }^{16}$.

Además de los personajes que intervienen en el acontecimiento, los artistas medievales integraron en la escena toda una serie de objetos simbólicos, algunos de los cuales acabaron por hacerse prácticamente imprescindibles. Ninguna época fue más sensible a lo sensible que la Edad Media que concebía el mundo como una escritura de Dios sobre los tiempos, un enorme libro en el que cada cosa y cada característica de las cosas es portadora de un significado profundo, más allá de su materialidad. El jarrón con azucenas ${ }^{17}$, el libro que María suele estar leyendo ${ }^{18}$ la ventana por la que penetran los rayos divinos ${ }^{19}$, la cama de la Virgen que aparece en ocasiones al fondo de la escena ${ }^{20} \ldots$, no son simples notacio-

13 Sobre la ambientación de la escena en las diferentes épocas y escuelas véase RoBB (1936), págs. 485 ss.; Reau (1955-59), II, Il, págs. 185-86; Spencer (1955), y Fournee (1968), págs. 225-35.

14 Protoevangelio de Santiago, XI, 1 y Evangelio del Pseudo-Mateo, IX, 1. Este último distingue una "preanunciación» en la fuente de la Anunciación propiamente dicha que habría tenido lugar tres días después mientras María hilaba la púrpura.

15 Marfiles de la colección Campo Santo Tedesco (Roma) y del Victoria \& Albert Museum (Londres) (s. v).

${ }_{16}$ Marfil del tesoro de la catedral de Milán (s. vI), Mosaicos de San Marcos de Venecia (s. XI), de la Capilla Palatina y de la Martorana de Palermo (s. XII), mosaico de Monreale (s. XII), Pala de oro de San Marcos (s. Xil) etc. En el arte occidental hay algún caso tardío y dudoso como la Anunciación de Andrea del Sarto (1512) en el Palacio Pitti de Florencia, dudoso porque la fuente al lado de la cual se encuentra María es de pequeño tamaño y parece más bien un atributo (aunque su simbolismo sea el mismo: la fuente de la vida) que un objeto integrante del ambiente.

17 Generalmente se le interpreta como una alusión a la pureza de María, aunque para Mâle su sentido es distinto: se trataría de una referencia a la primavera, la estación del año en la que habría tenido lugar el acontecimiento; como afirma San Bernardo, la Anunciación se produjo "en el tiempo de las flores" (Vid. MảlE (1986). pág. 265). Probablemente su origen haya que buscarlo en las Anunciaciones en la fuente en las que aparecía el jarro en manos de la Virgen.

18 Hace alusión a una extendida creencia que suponía que María se encontraba leyendo la profecia de Isaías sobre el Salvador (Isaías, 7, 14), en el momento de recibir la vista del ángel. Tal suposición cuenta con testimonios literarios desde la época carolingia (en el poema Krist), y artísticos desde los siglos Ix-X (Marfil de la escuela de Metz, Goloschmidt (1914-26), II, no 45). En la Baja Edad Media la idea la recogen algunas versiones de las Meditationes Vitae Christi y Ludolfo de Sajonia que apunta además un doble significado, siguiendo al Pseudo-Mateo: el libro sería también un atributo de la sabiduria de la Virgen. (Vita Cristi, V, $\mathrm{n}^{\circ} 163$ ).

${ }_{18}$ Ilustra la popular metáfora medieval de la luz que atraviesa el vidrio sin romperlo como símil de la concepción virginal (vid. infra nota 30), en ocasiones puede aparecer cerrada con una celosía que alude a la metáfora del Cantar de los Cantares (Vid. GotTlieb (1974)).

${ }_{20}$ Aparece en el arte en el siglo XIV pero se inspira en una alegoría de Ivo de Chartres (S. XII) en un comentario al Salmo $19,4-6$. 
nes ambientales sino simbolos destinados a ilustrar determinados aspectos de la condición de María o de la naturaleza del misterio de la Encarnación y su finalidad ${ }^{21}$.

El objeto de este trabajo es analizar el origen, evolución, difusión y significado de un motivo no demasiado frecuente en las Anunciaciones; un Niño, generalmente desnudo y portando una cruz, que aparece en la escena descendiendo desde el cielo hacia María. La presencia del Niño, un intento de hacer visible el misterio de la Encarnación, gozó de cierta popularidad en determinados ambientes durante los siglos XIV y XV pero despertó los recelos de los teólogos al considerar que podía inducir a creer que el cuerpo de Cristo había sido enviado ya formado desde el cielo en lugar de constituirse a partir de la sustancia materna como sostiene la ortodoxia católica. Fue por ello repetidas veces condenado llegando a proponerse la destrucción de las imágenes en las que éste aparecía, de tal modo que poco más de un centenar de ellas han llegado a nuestros días.

\section{DESCRIPCIÓN DEL MOTIVO}

Las Anunciaciones en las que aparece el motivo del Niño mantienen por regla general una serie de características comunes, un esquema básico a partir del cual se desarrollan una serie de variantes.

Lo más frecuente es situar en lo alto la figura del Niño desnudo que desciende del cielo «nadando» entre en rayos de luz ${ }^{22}$ (Fig. 1), precedido por la Paloma del Espíritu Santo ${ }^{23}$. Normalmente en lo alto aparece Dios Padre, de cuya boca o pecho parten los rayos entre los que desciende el

21 Sobre el simbolismo de los interiores véase SCHILLER (1972), I, pág. 49 y FouRnEe (1968).

22 En algunos casos desciende de pié (Misal de la Biblioteca Mazarina, cat. no 109); Anunciación de Giovanni Santi de Urbino, cat. $n^{\circ} 29$ ) o con los pies por delante (Altar Brenken, cat. $n^{\circ}$ 96). Puede asi mismo hacerlo sentado sobre una nube o resplandor (lglesia de $S t a . M^{a}$ de Manta, cat. $n^{0}$ 27). También pueden sustituirse los rayos de luz por una fístula (Tímpano de Wüzburg, cat. $n^{\circ} 54$ ) o una especie de cadena (Vidriera de Tamsweg, cat. $n^{\circ} 51$ ), recursos éstos de probable origen teatral.

23 La presencia de la Paloma no es un "pléonasme typiquement provincial" como sostiene Tolnay (TOLNAY (1959), pág. 71), sino un elerinento sustancial en toda Anunciación y especialmente en las que nos ocupan en las que se pretende resaltar el carácter trinitario de la Encarnación, aunque es cierto que en algunos casos excepcionales la Paloma no aparece, quizá porque los mismos rayos de luz simbolizan al Espíritu. Igualmente excepcionales son los casos en los que el Nin̄o precede a la Paloma (Anunciación de Domenico Panetti, cat. nº 30; Anunciación de Alonso de Sedano, cat. $n^{\circ} 88$, Fig. 5); Libro de Horas de Catalina de Cleves, cat. $n^{\circ} 102$ ) y aquí si que es posible que se trate de un error ya que no parece posible encontrar en los textos un justificación teológica para semejante disposición. 
Niño, aunque puede no encontrarse en la escena principal (algo frecuente si se trata de un retablo), o estarlo sólo de modo implícito en el halo de luz que penetra en la escena.

Una segunda posibilidad, relativamente abundante en obras bohemias y del norte de Italia, radica en representar al Niño antes de comenzar el descenso, todavía entre los brazos del Padre que se dispone a enviario y, en ocasiones, lo bendice. Así lo representan, entre otros, Lorenzo Veneciano, Mariotto di Nardo o el maestro de Johannes Von Neumarkt ${ }^{24}$.

Otras variantes, que habría que calificar de excepcionales, consisten en situar al Niño en los brazos del ángel, que hace ademán de entregárselo a María ${ }^{25}$, o fuera de la escena principal, en un luneto, óculo o medallón ${ }^{26}$.

\section{EL NIÑO}

Lo normal es representarlo desnudo, o a lo sumo envuelto en ligeros paños. Aunque generalmente es de pequeño tamaño (Fig. 1) e incluso puede no apreciarse fácilmente en una mirada rápida ${ }^{27}$, aparece siempre completamente formado, con un tratamiento anatómico infantil pero pocas veces de recién nacido. En ocasiones, incluso se transforma en un homúnculo, un pequeño hombrecito, llegando a representársele con barba y facciones de adulto para indicar que no se trata de un embrión sino de la manifestación visible del Logos ${ }^{28}$.

Es regla casi general representarlo con nimbo, a veces crucífero, o con un halo luminoso en torno a la cabeza. Puede aparecer también envuelto en una aureola luminosa más o menos realista. Un caso excepcional lo

24 Vid. cat. $n^{\circ} 8, n^{\circ} 18, y n^{\circ} 38$.

25 Retablo argénteo de Teramo (cat. $n^{\circ}$ 21) y Salterio del kaiser Maximiliano I (cat. $n^{\circ}$ 59).

26 Políptico de Arezzo (cat. $n^{\circ} 2$ ); Retablo de la Anunciación y los Santos Juanes (cat. $n^{\circ} 81$ ); Capilla de San Blas (cat. $n^{\circ} 84$ ), etc. Sin paralelos la Anunciación de Sta. Mariña Dozo (cat. $n^{\circ} 93$ ) en la cual el Niño aparece de pié con la cruz en la estancia de María. (sobre esta última véase GONZÁLEZ MONTAÑÉS (1994), págs. 173-176).

${ }^{27}$ El hecho de representarlo diminuto está de acuerdo con el relato de la Meditationes pero puede ser también una prevención frente a las condenas (ScHILLER (1972), pág. 46). En este sentido conviene notar que el tamaño del Niño mantiene aparentemente una relación con el carácter de la obra en la que aparece: cuanto más «popular», mayor es el Niño, mientras que en las obras de ambiente culto, o realizadas por artistas de prestigio, el Niño es de menores dimensiones ( $p$. ej. el Retablo de Mérode (Fig. 1) o la Anunciación de Aix, cat. no 98 y n² 11).

${ }_{28}$ Así, por ejemplo, en la Anunciación del Tríptico de la Coronación de la Academia de Florencia o en la de la iglesia de Sta. Mariña Dozo de Cambados (vid. cat. no 15 y n 93). 


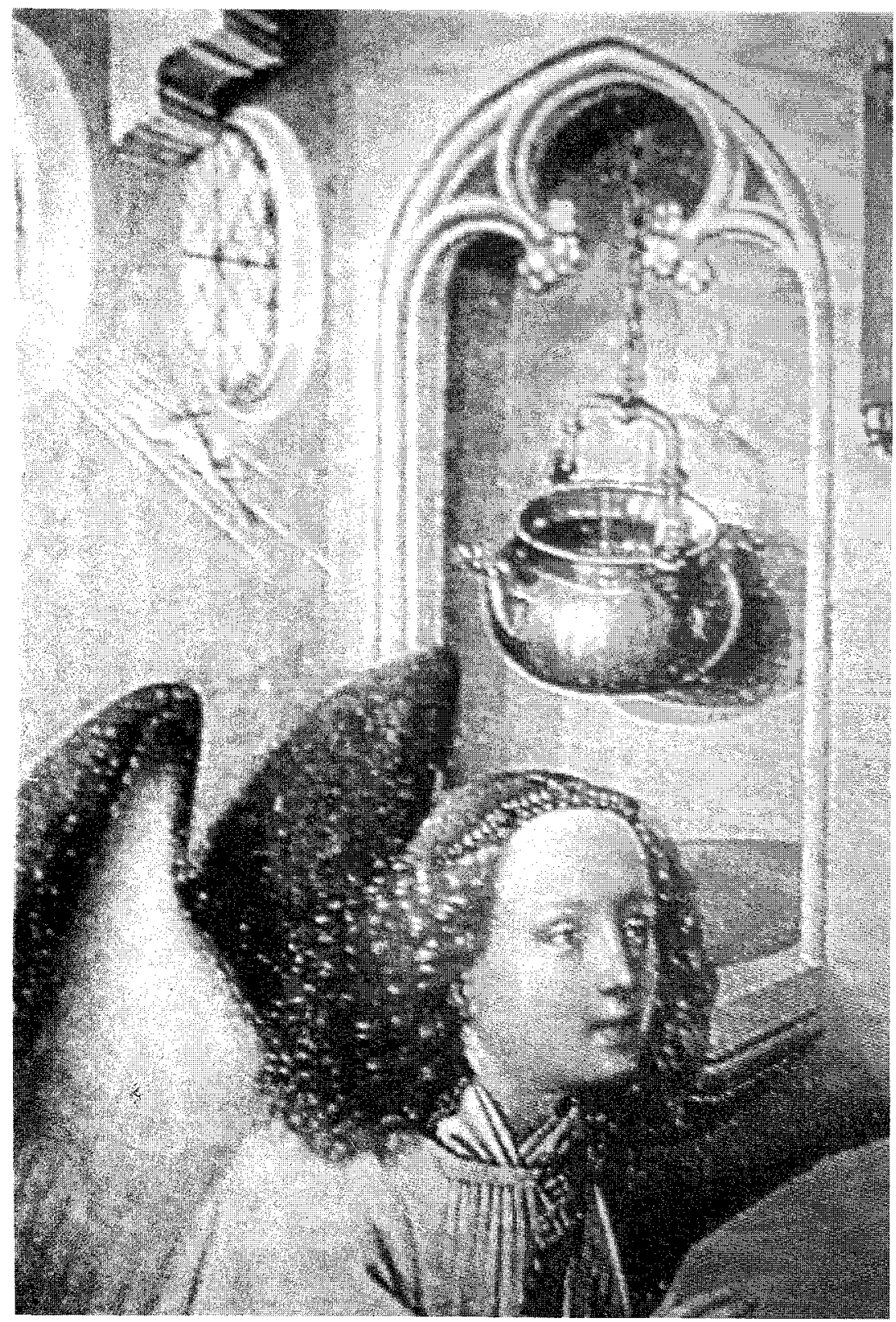

Fig. 1. Retablo de Mérode, Maestro de Flemalle 1425-28. Nueva York, Metropolitan Museum. 
constituye la Anunciación de Jaume Serra en el retablo del Convento del Santo Sepulcro de Zaragoza (cat. n 71) en la que sólo aparece el rostro del Niño convertido en un pequeño sol, probablemente siguiendo el relato de las Revelaciones de Santa Brígida ${ }^{29}$ que explota el conocido tópico de la luz que atraviesa el vidrio sin romperlo como símil de la concepción virginal ${ }^{30}$.

\section{SIGNIFICADO Y FINALIDAD}

Con la presencia en la Anunciación de un Niño desnudo que desciende del cielo, los artistas, o mejor sus mentores iconográficos, trataban sin duda de hacer visible el misterio de la Encarnación. La figura del Niño no pretende ser una representación del embrión de Cristo sino del Logos ${ }^{31}$. Recurrir para ello a uno de los símbolos tradicionales en el arte para la representación de las almas entra dentro de la ortodoxia a pesar de la confusión a la que puede inducir en la escena de la Anunciación ${ }^{32}$.

Cierto que hasta el siglo xv se mantuvo minoritariamente entre los teólogos la tesis, luego considerada herética, de la concepción in coelo ${ }^{33}$

$29 \quad$ «... entré en las entrañas virginales de mi Madre como el sol esplendente que entra por un purísimo cristal...» (Revelaciones, l, l, pág. 35).

3o La metáfora luminista tiene una larga tradición en la literatura mariana desde San Bernardo por lo que la nómina de referencias sería interminable. En España aparece en la obra de Berceo: «En el vidrio podría asmar esta razón/como lo pas el rayo de sol sin lesión/tu así engendraste sin nulla corruption" (Loores de la Virgen, copla 20, Biblioteca de Autores Españoles, LVII), en Gómez Manrique (Loores e suplicaciones a Nuestra Señora, Nueva Biblioteca de Autores Españoles, Madrid, XXII, pág. 147 "o virgo senper ynata/ de la cual nascio tu padre/ tu quedando tan entera/ como sana vedriera/ finca del sol traspasada") y en Fray Iñigo de Mendoza (Coplas de Vita Christi, $n^{\circ} 30$ «Tu quedaras tan entera/ de la preñez del infante,/ qual queda la vidriera/ quando en ella reuerbera/ el sol y passa adelante,/ que la dexa en aquel son/ que la hallo quando vino;/ pues asy sin corrupçion /seras de la encarnaçion/ del sacro Uerbo diuino").

${ }_{31}$ En muchos casos, los rayos de luz que envuelven al Niño parten de la boca del Padre e incluso el propio Niño parece salir de su boca en la mayoría de los alabastros ingleses en los que aparece el motivo (cat. $\mathrm{n}^{\circ}$ 122). El significado es claro, la Palabra=Logos, entra en la estancia de María al mismo tiempo que las palabras del ángel.

32 La figuración del alma por medio de un cuerpo humano desnudo, casi siempre asexuado y generalmente con rasgos infantiles es la más frecuente en el arte medieval y cuenta con numerosos precedentes precristianos. Véanse algunos ejemplos en GuERRA (1978), págs. 281 ss. figs. 42 , 49 y 50 .

3 El Oracional visigótico de Verona (antes del 732) incluye una oración que comienza asi: «Tu, Domine, cuius verbum caeli inhabitant ambitu, et terra inradiat caro factum..." (vid. IBÁNEEZMendoza (1975), pág. 322). Más preciso es Hugo de Saint-Cher cuando afirma sin titubeos: "Caro Christi primo fuit creata in coelo et post per miraculum inducta in uterum virgintis", (Scriptum super sententiis, cit. en GuLDAN (1968), pág. 156).

La diversidad de opiniones con respecto al misterio de la Encarnación queda perfectamente reflejada en el siguiente pasaje, tomado de la biografía del beato Giacomo della Marcha, en el que 
pero no parece que fuera la intención de los iconógrafos el ilustrarla, al menos en la mayoría de los casos. Que el objetivo de los artistas era la representación del alma de Cristo lo demuestran, además de los rasgos mencionados, las adaptaciones que se hicieron de la iconografía para temas como la Animación de Adán, con Dios Padre o la Trinidad enviando desde lo alto el alma de Adán en forma de un Niño desnudo ${ }^{34}$. Incluso se hizo extensiva la iconografía al campo secular, utilizándose el motivo del Niño desnudo para representar al alma humana enviada por Dios en el momento en el que se produce la concepción ${ }^{35}$.

Es el alma de Cristo, por tanto, lo que se quiere representar lo cual es perfectamente ortodoxo e incluso pueden señalarse algunos paralelos fuera del campo de las Anunciaciones: En el Pórtico de la Gloria de la Catedral de Santiago se utiliza también una figurilla, en este caso vestida y con barba, para representar el alma de Cristo en la Anástasis del arco izquierdo ${ }^{36}$, y en algunas crucifixiones, inspiradas sin duda en la iconografía que nos ocupa, aparece en lo alto Dios Padre recibiendo el alma de su Hijo muerto bajo la

se reproduce una conversación entre el Cardenal della Rovere (futuro Sixto IV) y el beato Giacomo:

"Alcuni anno una opinione che lo corpo de Christo venesse da celo et intrasse nel corpo de la Vergine Maria come fa una vena d'aqua che se parte da la vena et va per uno conducto fin alla fontana. Alcuni altri hano opinione che generato sia nel ventre de Maria de puro sangue (Ludolfo de Sajonia, por ejemplo, Vita Christi, cap. $V, n^{0}$ 206). Alcuni che fosse generato de superflui humori. Et chi à una opinione et chi à l'altra.

El beato Giacomo disse: Monsignior, lassate dire chi vole dire; credetemi che lo corpo de Christo fo generato nel ventre di Maria del sangue, de la carne, de la substantia de Maria" (Venanzio da Fabriano, Vita beati Jacobi de Marchia. Tomo la cita de LLOMPART (1964), pág. 191).

${ }^{34}$ Bible historiée de Guyart Desmoulins (Biblioteca Morgan, Ms. 394, fol. 5v) y Bible historiée de la Biblioteca Nacional de Paris (Ms. fr. 3, fol. 3), ambas de principios del siglo xv. Para estas representaciones véase Heimann (1938-39), págs. 50-52, Pl. 8 b y c.

35. Cf. la miniatura de la Vita Christi de Jean Mansel (Paris, Biblioteca del Arsenal, ms. 5206, fol. 174) en Heimann (1938-39), pl. 8d, o la escena del fol. 18 del Ms. 240 de la Biblioteca municipal de Valenciennes (en LEROQUIAs (1929), pl. 38).

Otros casos de adaptación del esquema podemos verlos en una inicial de un Misal de Felix $V$ de Saboya atribuido Peronet Lamy (Archivos estatales de Turín, Ms. j.b.II.6, fol. 2v (ca. 1430-40), incipit del segundo Domingo de Adviento). En ella, el motivo del Niño descendiendo del Padre se utiliza para hacer visible un versículo de isaías: "Pueblo de Sión, mirad que el Señor descenderá para salvar a las naciones..." (Vid. Edmunos (1964), págs. 130-132, fig. 14). También en el grabado de la portada de la edición de 1533 Nuevo Testamento de Lutero (Erhard Altdorfer) se representa a María arrodillada recibiendo la palabra de Dios en forma de Niño desnudo que desciende entre rayos llevando una cruz. (Vid. GuLDAN (1968), págs. 165-66, lám. 32a).

35. Es su alma lo que se representa ya que la tradición occidental desde $\mathrm{S}$. Agustín afirma que el cuerpo de Cristo permaneció en el sepulcro y sólo su alma descendió a los infiernos para liberar a los justos de la Antigua Ley. Es posible, sin embargo, que la imagen causara algunos problemas ya que se omitió en la versión orensana del Pórtico, el llamado Pórtico del Paraiso de la Catedral de Orense. 


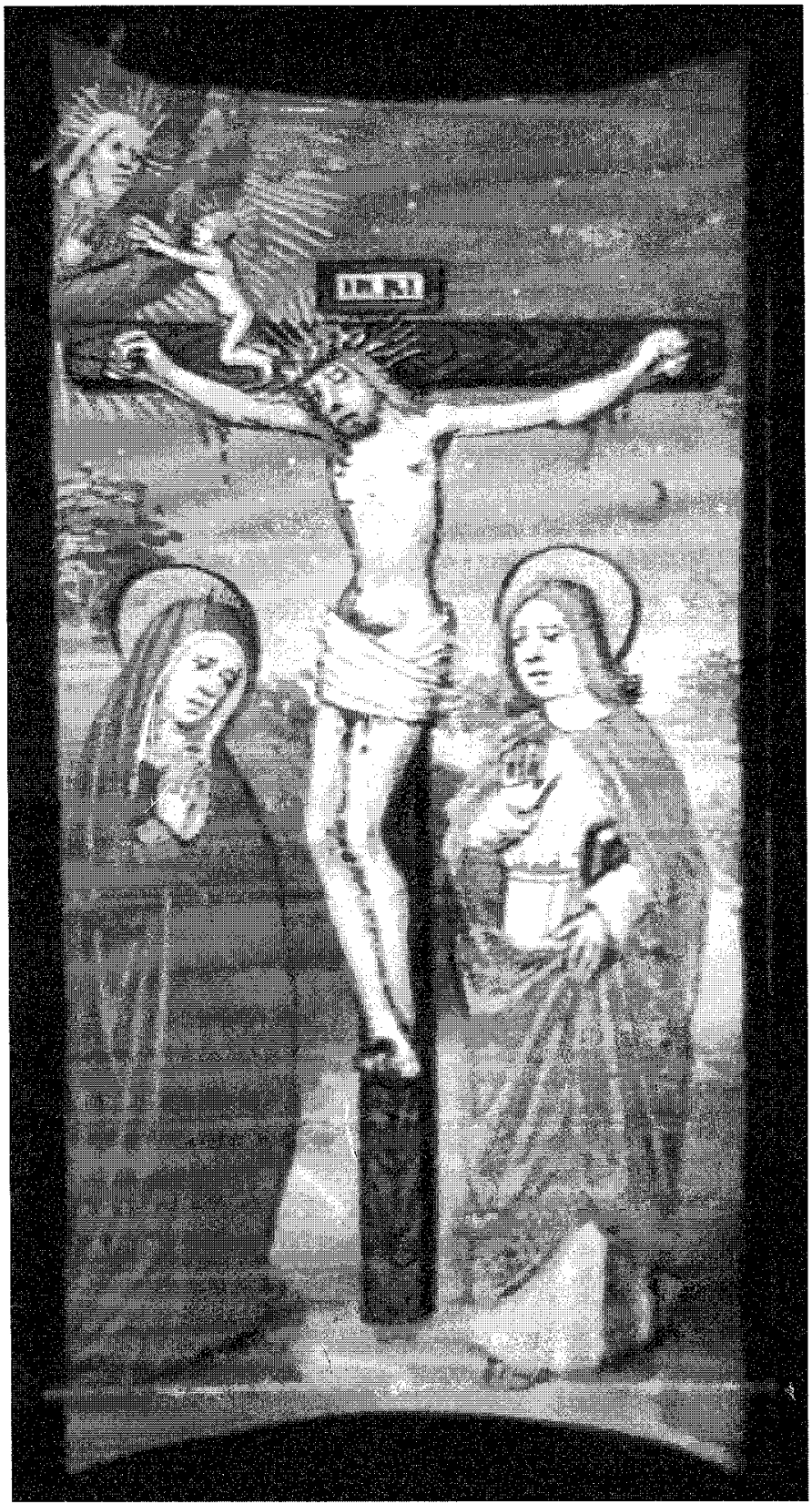

Fig. 2. Biblia de Carlos VIII, ca. 1500, Madrid, Biblioteca Nacional, Vit. 24-1, fol. 95. 
forma de un Niño desnudo, consiguiéndose así una genial recapitulación. Una vez cumplida en la cruz su misión redentora el Logos retorna al Padre en la misma forma en la que éste lo había enviado ${ }^{37}$ (fig. 2).

\section{SIMBOLISMO DE LA CRUZ}

En la mayoría de los ejemplos de la iconografía, el Niño desciende hacia María llevando en sus manos una cruz. La cruz no aparece en todos los casos aunque no creo que su presencia o ausencia deba atribuirse únicamente al capricho del artista como sostiene Robb ${ }^{38}$, ya que generalmente cuando falta es porque el contexto la hace innecesaria ${ }^{39}$. Con ella se trata obviamente de prefigurar la misión redentora de Cristo, siguiendo la tendencia bajomedieval ${ }^{40}$ a recapitular toda la historia de la salvación en función de su momento crucial: la Pasión ${ }^{41}$.

Con la presencia de la cruz, el motivo del Niño adquiere plena significación, resumiendo en una imagen el misterio de la Encarnación y su finalidad redentora que se cumplirá por medio del sacrificio de Cristo en la cruz. Incluso en algunas Anunciaciones en las que no aparece el motivo del Niño se plantea la misma proyección sustituyendo el cetro o bastón ${ }^{42}$ que suele llevar el ángel por una cruz que hace ademán de entregar a María.

37 Biblia de Carlos VIII de Francia (ca. 1500), Biblioteca Nacional de Madrid, Vit. 24-1, fol. 95. (Fig. 2).

Rosi (1936), pág. 525.

3: Así, por ejemplo, en el Lignum vitae de Pacino di Buonaguida (cat. $\mathrm{n}^{\circ}$ 1), donde el carácter cristológico-redencionista del conjunto hace que el significado del Niño resulte obvio, o en la Anunciación del retablo mayor de la Cartuja de Miraflores (cat. $n^{\circ} 90$ ), en el que la presencia eucarística del Cristo crucificado explicíta suficientemente el significado del Niño.

40 Es, efectivamente, una tendencia que se agudiza en la Baja Edad Media, especialmente en medios franciscanos. Sin embargo es tan antigua como el cristianismo. En una oración del ritual Ambrosiano se dice: "...ut qui angelo nuntiante, incarnationem cognovimus per passionem ejus et crucem ad resurrectionis gloriam perducamur", mientras que en el sacramentario de Gellone se reúnen el 25 de marzo las fiestas de la Annunciatio sanctae Mariae et passio domini nostri. (Vid. CABROL y LECLERQ (1926), col. 2253).

4i Como explicación del significado de la cruz, nada más claro que el texto de una de las coplas ( $n^{\circ}$ 206) de la Vita Christi de Fray lñigo de Mendoza titulada «Exclamacion al niño que traya la cruz":

"¡O paso muy dolorido/ mas, por cierto, verdaderol:/ no solo rezien nasçido,/ mas en siendo concebido/ te dio pena este madero/ que en el vientre do yazias/ en la tu diuinal luz/manifiestamente veyas/ el triste fin de tus dias/ auer de ser en la cruz». (Vid. la edición de J. Rodríguez Puertolas, Madrid, Gredos, 1968, pág. 411).

1: El cetro, atributo de los heraldos heredado de Mercurio, corrientemente convertido en virga viatoria, puede también transformarse en un lirio, alusivo a la pureza de María. (sobre el lirio y el bastón véase REAu (1955-59), II, II, pág. 183). 
Hay ejemplos muy antiguos de esta transformación en el arte copto, apareciendo en occidente en la época carolingia y otoniana ${ }^{43}$. En el románico es relativamente abundante (capitel de la Puerta de Miègeville, portada de Leyre, capiteles de Jaca, Alet y Chauvigny $\ldots{ }^{44}$ ) y, aunque quizá en algunos casos la cruz haya que verla más como una insignia o atributo litúrgico que como una alusión a la Pasión ${ }^{45}$, en otros más tardíos creo que es evidente la intención de resaltar la finalidad salvadora de la Encarnación ${ }^{46}$.

\section{CARÁCTER TRINITARIO}

La presencia de Cristo-Logos junto a Dios Padre y la Paloma del Espíritu Santo, confiere a las Anunciaciones con Niño un carácter trinitario que las convierte en la expresión visible de la concepción bajomedieval de la Encarnación como obra de la Trinidad.

Ya Santo Tomás en la Summa señala que la Encarnación es la obra de toda la Trinidad ${ }^{47}$, idea que recogen la Meditationes:

«Porque debes saber que la excelente obra de la Encarnación, la hizo toda la Trinidad aunque sólo se encarnó la persona del Hijo, como si ai que se viste una túnica le ayudasen dos por los lados tirándole de las mangas. [...] Pues aunque en todas partes está la Santísima Trinidad, no obstante debes considerar que ahora está allí de una manera singular, por razón de que la operación que alli se obra es también del todo singular. [...] Mira, por Dios, aquí, y considera cómo toda la Trinidad está allí esperando la respuesta y consentimiento de esta su hija..." ${ }^{48}$.

Y que más tarde hará suya Ludolfo de Sajonia:

"Deus, que enviou o ângeo, foi tôda a Trindade, ainda que ao Padre soo seja atribuído. O Padre enviou, porque a el perteencia o cuidado de proveer do Filho e do Spiritu Santo e da Sposa e Madre. O Filho enviou também, porque el havia de viinir em a Virgen. O Spíritu Santo outrossi enviou, porque el houve de santificá-la e cobri-la da sua sombra" ${ }^{49}$.

43 Cf. el Codex Egberti, en KünstLe (1926), fig. 147.

44 Véanse otros casos y las referencias de los citados en MoRALEJo (1977), págs. 191-92.

45 Moralejo (1977), pág. 194.

46 Véase, por ejemplo, la Anunciación de Diego de la Cruz en el Tríptico de la Adoración de Jos Magos de la Catedral de Burgos, en Silva Maroto (1990), II, págs. 382-83, fig. 84, y (1995), cat. 12 , págs. 50 ss. fig. pág. 51 .

47 Summa Theologica, 3, 31, art. 5, y 3, 32, art. 3.

${ }_{48}$ Meditationes Vitae Christi, cap. IV , págs. 14-17.

49 Vita Christi, cap. $V, n^{\circ} 146$ (ed. portuguesa, fol. 14r, facsímil pág. 61). En todas las referencias a la Vita Christi de Ludolfo de Sajonia cito por el facsimil de la edición portuguesa de 1495, Rio de Janeiro, 1957. 
Parafraseando al Pseudo-Buenaventura:

"E teemos desto semelhança em très que vestem uum de si meesmos dos quaaes se pode dizer que todos juntamente fazem unha obra e aquêlo que faz uum faz o outro, e nom é porém vestido senom uum".

Y citando a San Agustín:

"Quaaesquer obras de cada unha das pessoas da Trindade, a Trindade as obra e faz, e a qualquer que obra, as outras duas pessoas adjudam" ${ }^{50}$.

Como señala Gössmann ${ }^{51}$, la interpretación trinitaria del Dominus tecum de los comentarios tardomedievales ${ }^{52}$ ha sido transportada en las Anunciaciones con Niño al campo visual.

\section{ORIGEN Y DIFUSIÓN}

\section{Origen}

Aunque desde finales del XIX abundan los trabajos en los que se hace referencia al motivo del $\mathrm{Niño}^{53}$, fue Adelheid Heimann la primera en sugerir un origen, que para ella habría que buscar en Francia, en concreto en las Biblias Moralizadas ${ }^{54}$. Éstas suelen incluir, como correspondencia tipológica del episodio en el que el Faraón hace vestir a José con ricas vesuiduras (Gen. 41, 42), una escena en la que Dios Padre entrega a la Virgen un niño nimbado al que «viste» con la carne de María ${ }^{55}$. Una imagen similar, aunque con la presencia de un ángel entregando el niño desnudo a la Virgen, o bien ésta sosteniéndolo en su seno, se utiliza como tipo moralizado de la cocción del pan del sacrificio (Lev. 2,4$){ }^{56}$.

so Vita Christi, cap. V, nº 191 (ed. portuguesa, fol. 18, facsímil pág. 75).

s1 GóSMAAN (1957), págs. 279-80.

5. Véase, como ejemplo, el comentario de Ludolfo de Sajonia en la Vita Christi: «Em esta palavra "Dominus tecum", que quer dizer "o Senhor é contigo", se demostra aquela ineflabel uniom e obia que tôda a Trindade acabou em ela quando the prougue tomar a sustancia da sua carne em unha pessoa da natureza divinal, assi que Deus fôse feito homem e o homem Deus». (cap. V, 169, fol. XXl, facsímil pág. 67).

Gi Grimoüard (1874), IV, págs. 112 ss.: Beissel. (1904), págs. 442-43, y (1909), págs. 600601; HIRN (1912), págs. 283 (nota 27) y 314-15; KüNSTLE (1928), I, págs. 339-40.

54 HeIMANN (1932), págs. 42-43.

5. Heimann se refiere en concreto al fragmento de la Bodleian Library (ms. 270b, primera mitad del S. XIIi), pero la misma escena aparece en otros manuscritos de la serie (Vid. LABORDE (1911-27), vol. l, lams. XXVII, LIX y Cl; vol. II, lams. CVIIl y CCXCVIl y vol. IV, Lam. DXCll).

(ij) La imagen aparece en las Biblias de Viena (Biblioteca Nacional Austriaca, cod. 1179, fol. 44 y cod. 2554, fol. 27, en LABORDE (1911-27), IV, Lam. DCLXXVII, y HAusSHERR (1992), 27v b, y en el fragmento de Oxford (ms. 270b, fol. 59r (RoBB (1936), f. 43). 
Sin embargo, como señala Robb ${ }^{57}$, estas escenas no son en realidad. Anunciaciones. En ellas no se pretende representar el episodio de la Salutación angélica -las Biblias Moralizadas incluyen Anunciaciones en las que no aparece el motivo del Niño ${ }^{58}$-, sino el hecho mismo de la Encarnación ${ }^{59}$. Por otra parte, en las escenas aludidas no aparecen nunca los rayos del luz procedentes del Padre ni el sentido de descenso -emisus caelitus ${ }^{60}$ - que acompañan al Niño en los ejemplos plenamente desarrollados ${ }^{61}$.

Estas razones, unidas al hecho de que en Francia la Anunciación con Niño aparece tardíamente ${ }^{62}$, llevan a Robb a rechazar la hipótesis de Heimann y, aun admitiendo la posibilidad de una cierta influencia tipológica, a negar que las Biblias Moralizadas hayan sido la fuente iconográfica para las Anunciaciones con Niño posteriores ${ }^{63}$.

\footnotetext{
57 RoBB (1936), pág. 523.
}

58 BNA, cod. 2556, fol. 61 (HAussherR (1992), $61 \mathrm{v}$ d, y fragmento del Museo Británico (Harley 1527, fol. 6V),(LABORDE (1911-27), IV, Lam. CCCCLXXVII).

59 En este sentido conviene recordar que el texto de las Biblias Moralizadas ha sido puesto en relación con las Postillae del dominico Hugo de Saint-Cher (LABORDE (1911-27), V, págs. 82-86), uno de los teólogos medievales que sostenían que la carne de Cristo había sido formada en el cielo entrando luego milagrosamente en el cuerpo de María (vid, supra nota 33).

6o La expresión es de San Buenaventura (Lignum vitae, 3), pero la idea no es nueva. El propio Cristo responde a Nicodemo, según el relato evangélico: "Nadie sube al cielo sino el que bajó del cielo, el Hijo del hombre que está en el cielo" (Jn. 3, 13), afirmación que se convierte en verdad de fe en el Credo romano «Qui propter nos homines et propter nostra salutem descendit de caelis. Et incarnatus est de Spiritu Sancto ex Maria Virginé, et homo factus est [...]. Et ascendit in caelum". No resulta por tanto extraño que las referencias a Cristo descendiendo del cielo aparezcan constantemente en el pensamiento medieval. Así las Meditationes afirman parafraseando el Salmo 19, 6: "Hoy, saliendo de lo más alto del cielo, se alegró como gigante, para correr su camino, y se encerró en el huerto del vientre virginal.» (cap. IV, pág. 19), y en similares términos describen el beato Juan de Ávila el misterio de la Encarnación en uno de sus sermones: «Descender quiero, dice Dios [...], que, por el gran amor que nos tuvo se bajó y se encerró en el vientre de la Virgen determinado de pagar y padecer y morir por todos los hombres..." (Obras completas, B.A.C., Madrid, 1952, vol. 2, pág. 1.015), y el Arcipreste de Hita el primer gozo de María: "... desque el mandato oviste/ omilmente rrescebiste/ luego Virgen concebiste/ al Fijo que Dios enbia". (Libro de buen amor, ed. de Jacques Joset, Madrid, Espasa-Calpe, 1974, pág. 20). Nada tiene de extraño, por tanto, que los artistas adoptaran el motivo del Niño que simplemente visualizaba una idea que era un lugar común en la teología.

i1 Tampoco aparece la cruz que suele portar el Niño aludiendo a su misión redentora, pero ésta no es un elemento imprescindible en la iconografía. (Vid. supra p. 22).

${ }_{62}$ Hay un caso relativamente temprano, la Anunciación Sachs (ca. 1390, cat. $n^{\circ} 106$, Fig. 4), pero su procedencia francesa es dudosa (vid. PANOFSKY (1953), pág. 392) y, en todo caso, pertenecería a un ámbito totalmente italiano (la escuela de Avignon). En la Francia del Norte, donde fueron iluminadas las Biblias Moralizadas, el primer ejemplo conservado es de hacia 1430 (ms. 157 de la Biblioteca Morgan, foi. $57 r$, cat. $n^{\circ} 107$ ), una fecha en la que ya hacia más de cincuenta años que el motivo se habia convertido en algo habitual en Italia, Bohemia, o España.

${ }_{63}$ RobB (1936), págs. 523-24. En un trabajo publicado en 1939 Heimann se daba por enterada de las críticas de Robb y mostraba su desacuerdo anunciando un estudio más completo sobre el tema (HEIMANN (1939), pág. 51, nota 6). No sé, sin embargo, si llegó a publicarlo. 
Para Robb, la iconografia sería de origen italiano, concretamente florentino, apareciendo por primera vez, hacia 1310-20, en el Lignum vitae de Pacino di Buonaguida (cat. $n^{\circ} 1$ ), una obra claramente inspirada en el texto del mismo título de San Buenaventura, texto que permitiría explicar la presencia de dos Niños en la Anunciación del árbol - uno sobre el cuello de Maria y otro descendiendo del Padre-, un hecho que no se repetirá en los ejemplos posteriores ${ }^{64}$.

A partir de la obra de Pacino, Robb plantea un cuadro de cerradamente difusionista. En primera instancia el motivo se difundiría por Italia apareciendo luego en Bohemia y más tarde en la Península lbérica, Flandes, Francia, Inglaterra, etc. Para él la iconografía es una creación individual, basada en un texto concreto y todos los demás casos serían fruto de la difusión, siempre en ambientes de clara influencia italiana. Tan sólo en el caso inglés, admite, aunque con reservas, la posibilidad de una invención independiente derivada de la puesta en escena teatral, aunque teniendo en cuenta que la referencia a la presencia del Niño en la Anunciación aparece en una fecha avanzada (1468) y solamente en uno de los muchos textos conservados, descarte al teatro como vehículo de difusión y popularización del motivo ${ }^{65}$.

El trabajo de Robb se convirtió pronto en un clásico sobre el tema, y los que con posterioridad se ocuparon del asunto, o bien aceptaron prácticariente sin reservas su cuadro de difusión y sus hipótesis sobre el posible origen del motivo ${ }^{66}$, o desconocían su trabajo y no se ocuparon del problema del origen ${ }^{67}$. Tan sólo Dubreuil ${ }^{68}$ ha planteado objeciones a la tesis de Robb, señalando el carácter incompleto de los primeros ejemplos italianos (el medallón del Lignum vitae de Pacino y la Anunciación del altar

${ }_{64}$ RoBB (1936), pág. 524. El texto es el siguiente: «... y al punto, por obra de aquella virtud, fue formado el cuerpo, creada el alma, y entrambos unidos a la Divinidad en la persona del Hijo quedando asi hecho Dios y hombre, salva la propiedad de las dos naturalezas» (cito por la traducción castellana que ofrece la edición bilingüe de las Obras Completas de San Buenaventura, Madrid, BAC, 1946, vol. Il, pág. 301).

${ }_{65}$ ROBB (1936), pág. 525, nota 165.

aj SchapiRo (1945), pág. 183, se remite a Robb sin entrar en la cuestión del origen; REAU (1955-59), pág. 191, se abona también a la lesis de Robb sobre el origen italiano aunque señala, sin citar ejemplos concretos, una posible inspiración en los iconos bizantinos de la Anunciación en los que el Niño Jesús aparece sobre el pecho de la Virgen (Vid. infra nota 74); KanE (1974), págs. 201 ss. sigue también a Robb.

g7 LIPINSKr (1954); TOLNAY (1959), pág. 71; LLOMPART (1964). Sólo Lipinsky apunta la posibilidad de que las Meditationes del Pseudo-Buenaventura hayan podido servir de fuente de inspiración para los iconógrafos pero lo hace de pasada y ni siquiera cita el texto correspondiente (LIPINSKY (1954), págs. 255 ss.).

6 Dubreull (1987), págs. 75-76. 
de Arezzo de Pietro Lorenzetti, cat. $n^{0} 1$ y 2 ), en ninguno de los cuales aparece la cruz que suele portar el Niño en ejemplos posteriores. El primer caso en el que aparece la cruz habría que buscarlo en Bohemia (Antifonario del convento de Vorau, ca. 1360, cat. $n^{\circ} 40$ ), una década antes que en Italia.

Tanto Robb como Dubreuil, más allá de sus discrepancias a la hora de establecer el primer ejemplo de la iconografía, plantean un proceso de creación ex nihilo, sin considerar la existencia de toda una serie de precedentes en los que se intenta hacer visible la relación existente entre la Anunciación, la Encarnación y la finalidad redentora de ésta, una asociación que había sido establecida sólidamente por la teología desde los primeros tiempos del cristianismo, aunque no alcanzara expresión plástica en una imagen concreta.

Las Anunciaciones con el árbol del Paraíso ${ }^{69} \mathrm{O}$ las que incluyen la Fuente de la Vida o a Eva con la serpiente tienen en común la misma intención de engarzar la Anunciación en el contexto de la Historia de la Salvación ${ }^{70}$. Es también frecuente, para destacar la finalidad redentora de la Encarnación, asociar en una misma obra la Anunciación con la Crucifixión ${ }^{71}$ y no faltan, desde el siglo $x$, ejemplos de Anunciaciones en las que aparece el motivo del Niño, si bien no aparece nunca descendiendo del cielo y es en realidad del Niño Jesús, no el Logos.

Especialmente interesantes como precedentes de la iconografía que nos ocupa son dos casos hispanos, inadvertidos para los que con anterioridad de ocuparon del tema: la Biblia de San Isidoro de León (960) ${ }^{72}$ y el Beato de Fernando I (1047) (Fig. 3). En ambos códices se incluyen, en los árboles genealógicos que preceden a la obra, sendas Anunciaciones compuestas por un medallón con María y el niño en el regazo y, fuera de éste, al ángel

69 Marfil renano del Museo de Berlín (S. IX), en SchILLeR (1971-72), f. 77. Fresco de Casteiprio (ibid, f. 79). Puerta de bronce de la catedral de Monreale (ibid. f. 78).

to Vid. SchILLER (1971-72), págs. 40-42. Respecto a la presencia de Eva en la Anunciación conviene recordar el conocido tópico medieval -aunque con testimonios desde el $S$. $\|-$ del juego de palabras que asocia a Eva con María. EI AVE de la Anunciación es el nombre de EVA vuelto al revés, María es la nueva Eva que, al asumir la Encarnación, borra el pecado de su antecesora. (Sobre este tema véase GULDAN (1964)).

71 Véase, por ejemplo, el carolingio Diptico Harrach (SCHILleR (1971-72), 1. 76). Es importante no olvidar que desde sus origenes paleocristianos (frescos de las catacumbas de Priscila y de los santos Pedro y Marcelino, mosaicos de Sta. $M^{a}$ la Mayor...), la Anunciación aparece siempre en coniextos cristológicos, el carácter mariano no lo adquiere hasta la época bajomedieval cuando el pensamiento cristológico tradicional y la nueva teología mariana convergen en el tema de la Anunciación.

72 Delclaux (1973), fig. pág. 37. 


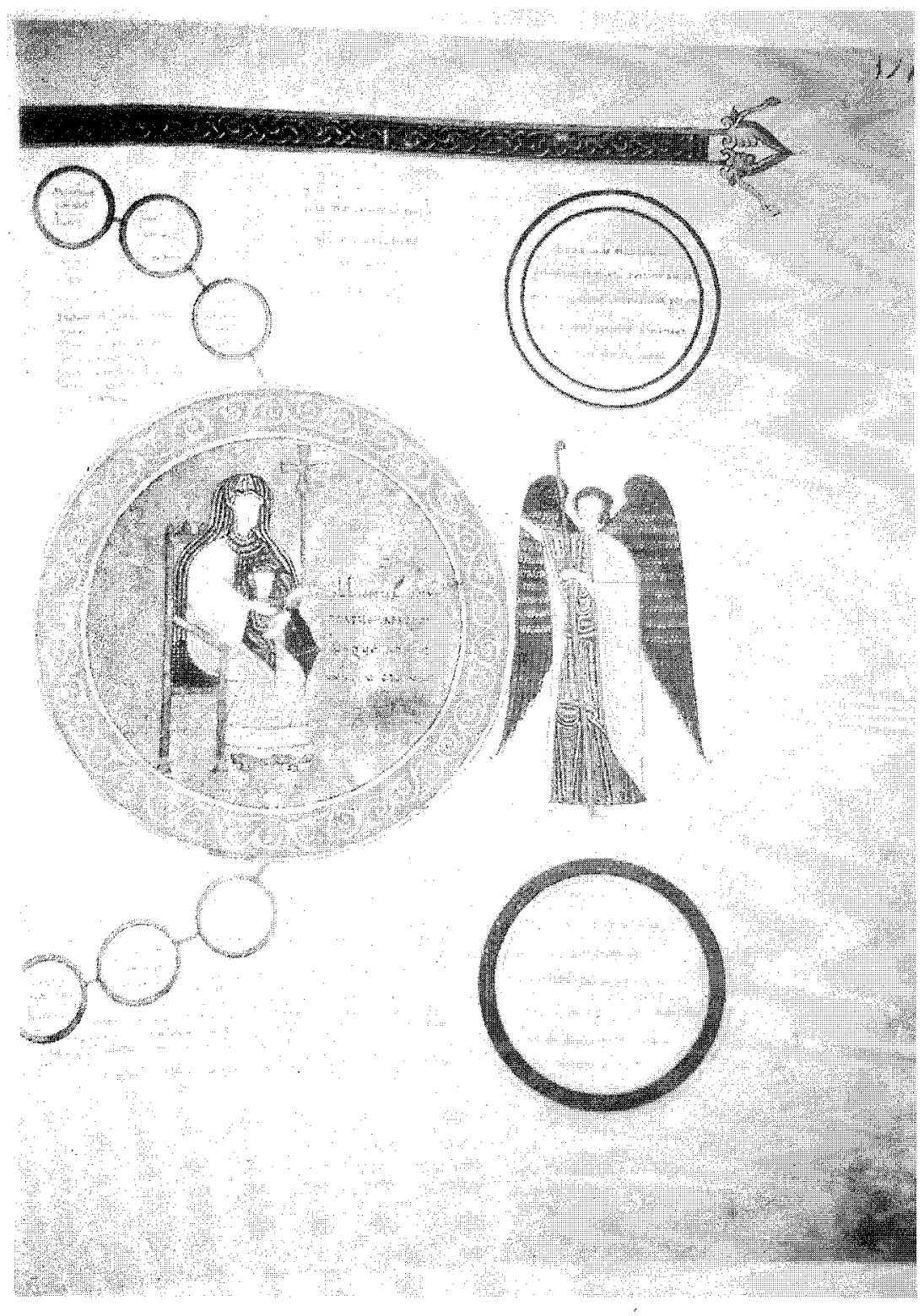

Fig. 3. Beato de Fernando I, 1047, Anunciación. 
anunciador. En el caso del Beato el Niño lleva en su mano una cruz patada de tipo asturiano con un largo astil, evidente alusión a la misión redentora.

Existen también en el arte bizantino algunas Anunciaciones -que derivan de las Vírgenes tipo Platytera ${ }^{73}$-_, en las que aparece del Niño sobre el pecho de María ${ }^{74}$ y aunque no parece probable que hubieran podido influir en los iconógrafos occidentales ${ }^{75}$, su existencia es significativa por cuanto testimonian un fenómeno de convergencia: la necesidad de expresar plásticamente conceptos teológicos similares llevó a los artistas orientales y occidentales a soluciones análogas. Ello permite suponer, al menos como hipótesis de trabajo, la existencia de varios focos de creación independiente en occidente sin tener que recurrir necesariamente al difusionismo para explicar la presencia del motivo.

A la luz de los precedentes mencionados, la iconografía de la Anunciación con Niño aparece como el fruto de una lenta evolución, de una serie de tanteos sucesivos que cristalizarán a mediados del siglo xIV en una imagen en la que se hace claramente explicita la secuencia AnunciaciónEncarnación-Redención, resaltando el carácter trinitario de la Encarnación y prefigurando, por medio de la cruz, los episodios de la Pasión.

Las ideas que informan la nueva iconografía no son nuevas en la teología occidental, pero en la época bajomedieval pasan al primer plano y aparecen insistentemente en la teología franciscana que hace especial hincapié en la Encarnación como obra de la Trinidad y manifiesta una tendencia constante a ver prefigurada la Pasión en todos los episodios de la vida de Cristo. Ya Robb había señalado la influencia de un texto de San Buenaventura en la Anunciación de Pacino di Buonaguida pero resulta imposible hacer extensivo su influjo al resto de las Anunciaciones en las que no vuelven a aparecer los dos Niños con los que Pacino pretende hacer visibles la naturaleza humana y la divina de Cristo ${ }^{76}$.

\footnotetext{
73 La Platytera es una Virgen embarazada que muestra al Niño en un medallón circular que cuelga sobre su pecho (el clípeo es, desde la antigüedad, simbolo de una presencia invisible). Sobre este tema véanse los trabajos clásicos de StEINBERg (1932), Bord (1933) y Rosenau (1944).

${ }^{74}$ Icono de Ustyug (Escuela de Novgorod, S. XII, Moscú, Galería Tretiakov), en SchilLER (1972) fig. 98).

75 La idea de mostrar por transparencia el embarazo de María no es deconocida en occidente pero suele utilizarse en vírgenes aisladas (las populares vírgenes de la Esperanza) o en la escena de la Visitación (vid. Bord (1933), pág. 81 ss., FEUdale (1957), págs. 8 ss. y VerHEYEN (1964). Sólo conozco dos casos, ambos de procedencia austríaca, en los que se aplicó el procedimiento a una Anunciación: EI Libro de Leyendas de Regensburg (2 ${ }^{a} / 2$ XIII) y una Biblia (ca. 1330) hoy en el museo de Budapest (cat. $n^{\circ} 36$ ).

${ }^{76}$ Toda la teología franciscana, y especialmente la de S. Buenaventura, aparece obsesionada por el problema del aspecto corpóreo de la Encarnación (Vid. Rosenau (1944)).
} 
Hay sin embargo una obra, las Meditationes vitae Christi ${ }^{77}$, verdadero compendio de la Pietas franciscana, que ejerció una notable influencia en la configuración del sentimiento religioso popular bajomedieval ${ }^{78} \mathrm{y}$ en el campo de la creación artística ${ }^{79}$, en cuya descripción de la Salutación angélica aparecen con vívidas imágenes todos los componentes que habitualmente están presentes en las Anunciaciones con Niño:

«... Porque debes saber que la excelente obra de la Encarnación, la hizo toda la Trinidad aunque solo se encarnó la persona del Hijo. [...] Y arrodillada con profunda devoción, según se lee en sus revelaciones, y con las manos juntas, dijo: He aquí la esclava del Señor, hágase en mí según tu palabra. En este mismo instante, todo un hijo de Dios entró en el seno de la Virgen y tomó de ella carne, quedando al mismo tiempo todo en el seno del Padre [...] $Y$ en el mismo instante, criada $e$ infundida el alma en el cuerpo, quedo hecho perfecto hombre con la debida disposición corporal, aunque muy pequeñito, de modo que crecía naturalmente en el vientre como los demás; pero la infusión del alma y la distinción de miembros no fue retardada, como sucede con los otros, y era tan perfecto Dios como perfecto hombre, y tan sabio y poderoso como lo es ahora [...] Hoy el Hijo ha recibido del Padre la nueva obediencia de obrar nuestra salvación. Hoy, saliendo de lo más alto del cielo, se alegra como gigante, para correr su camino y se encerró en el huerto del vientre virginal. Hoy también se ha hecho uno de nosotros y hermano nuestro,

"Tradicionalmente atribuidas al propio San Buenaventura (aparecen incluidas en su Opera Omnia, Venecia, 1761), fueron separadas del cuerpo de su obra por los PP. editores de Quaracchi en su edición moderna de las obras del seráfico doctor (Florencia, $X$ vols. en IX, 1882-1902). Los problemas de la autoría aún no están totalmente resueltos pero si el escrito no es totalmente bonaventuriano, si fue franciscana la mano que lo escribió. Se han propuesto diferentes atribuciones (Jacobo de Cordone, Giovanni de San Gimignano...) y se discute todavía si la versión latina antecede a las romances o a la inversa. La atribución a Giovanni Cauli di San Gimignano cuenta a su favor con el testimonio de Bartolomeo de Pisa quien en el Liber conformitatum (1385-90) afirma: "Frater Joannes Caulibus, magnus praedicator et devotus, qui meditationes super evangelia fecit pulchra» (Vid. OLIGIER (1921-22). Sin embargo, los problemas que plantea la personalidad de Caulibus (está documentada históricamente la existencia de dos personajes con el mismo nombre, uno compañero de San Francisco y otro tardio, vivo todavía en 1374) hacen dudar del testimonio de Bartolomeo de Pisa, el único por otra parte que las atribuye a Caulibus, (Vid. Stalling (1963)). Otro problema es el de la cronología: los que aceptan la tesis de Oligier fechan la obra hacia 1290-1310 pero olvidan que hay testimonios artísticos concluyentes de que la obra circulaba ya hacia 1260. (Vid. SIMI VARANELLI(1992)).

${ }_{78}$ De su popularidad dan fe los numerosos códices que se conservan -más de 200 - y las frecuentes traducciones y ediciones que aparecen hasta bien entrado el siglo XvI. Otro hecho que prueba, y al tiempo explica, su difusión es la influencia que ejercieron en el teatro de los siglos XIV y XV (Vid. D'ancona (1891, 2ª 1970), págs. 129-33; Mâle (1904); Doglo (1982), págs. 252-53, y DE BARTHOLOMAEIS (1924), págs. 210-12).

79 La influencia del texto en la renovación de la iconografía fue destacada en primer lugar por THODE (1885), págs. 42-181 y más tarde, con especial énfasis, por MÂLE (1908), cap. I, págs. 27 ss. y cap. IV, págs. 145 ss. (en concreto para el tema de la Anunciación, págs. 29 ss., aunque no se refiere al motivo del Niño). Véase también GILLET (1912), págs. 110-126 y, recientemente, SIMI VARANELLI (1992). 
y ha comenzado á peregrinar como nosotros. Hoy ha descendido del cielo la luz verdadera para alejar y disipar nuestras tinieblas. Hoy el pan vivo, que da vida al mundo, es cocido en el horno del seno virginal. Hoy el Verbo se hace carne, para habitar entre nosotros. Hoy han sido oídos y tenido su cumplimiento los clamores y deseos de los patriarcas y profetas... ${ }^{80}$.

Creo que es importante destacar el papel que el texto ha debido de jugar en la creación de la imagen que nos ocupa, su difusión y la influencia que ejerció en artistas e iconógrafos autorizan a pensarlo así. No pretendo, sin embargo, que sea éste la única fuente de la iconografía. Las ideas que recoge el autor de las Meditationes no son completamente nuevas y en buena parte pueden haber sido inspiradas por el arte, por ello conviene no olvidar la influencia que, desde el campo de la imagen, pudieron ejercer algunos prototipos como los anteriormente señalados.

\section{Difusión}

El motivo del Niño no suele aparecer en obras de primera línea, sino en trabajos de carácter retardario, burgués o incluso claramente popular, y será precisamente en estos ambientes en los que la imagen perdurará, a pesar de las condenas, hasta bien entrado el siglo xvı. Es en el ámbito privado de los libros de horas, de los altares portátiles y de las imágenes de devoción donde el motivo alcanza su pleno desarrollo. Es fundamentalmente un motivo pictórico (la condena de San Antonino se refiere concretamente a los pictores), apenas utilizado en la escultura ${ }^{81}$, aunque puede encontrársele prácticamente en todos los campos de la actividad artística, desde la eboraria ${ }^{82}$ hasta la vidriera ${ }^{83}$, pasando por el grabado ${ }^{84}$, la metalistería ${ }^{85}$, y la tapicería o el bordado ${ }^{86}$.

Es lógico pensar que la vía principal de propagación del motivo haya sido la circulación de manuscritos. L.a miniatura es, efectivamente, uno de

so Meditationes Vitae Christi, cap. IV, De la Encarnación de Jesucristo, págs. 13-20. La descripción de las Meditationes la reproduce, casi literalmente, Ludolfo de Sajonia en su Vita Christi (cap. V, 206-07), una obra, que como la que le sirve de inspiración, gozó de enorme popularidad a pesar de las dudas que se plantearon sobre su ortodoxia.

81 Poco más de una decena de casos de los cuales siete son relieves de alabastro (cat. $\mathrm{n}^{\underline{0}}$ $117, n^{0} 120, n^{0} 121, n^{\circ} 122, n^{\circ} 123, n^{\circ} 124$ y $\left.n^{0} 125\right)$. En la escultura monumental aparece tan sólo en cuatro ocasiones (cat. $n^{0} 26, n^{2} 54, n^{\circ} 65$ y $n^{\circ} 93$ ).

2 Vid. cat. $n^{\circ} 94$.

83 Tres casos, cat. $n^{2} 51, n^{2} 66$, y $n^{0} 119$.

9.4 Cat. $n^{\circ} 56, n^{\circ} 59, n^{2} 99$ y $n^{2} 127$.

85 Cat. $n^{\circ} 97$.

s6 Cat. $n^{\circ} 58, n^{\circ} 68, n^{\circ} 105$ y $n^{\circ} 112$. 
los ámbitos en los que aparecen mayor número de casos ${ }^{87}$ y especialmente adecuado por la movilidad de las piezas para servir de vehículo de difusión. Un testimionio evidente del funcionamiento del mecanismo lo tenemos en Bohemia, donde el motivo aparece en primer lugar en la miniatura tras el viaje a Italia del emperador Carlos IV de Luxemburgo en 1356.

Otro posible medio de difusión pudieron haber sido los retablillos de alabastro ingleses, piezas viajeras como atestigua su dispersión por todo el continente, en los que el motivo fue utilizado con frecuencia. No hay que olvidar tampoco el papel de los libros de modelos y de los grabados ni, en última instancia, de los desplazamientos de artistas en busca de trabajo. El caso valenciano es un buen ejemplo de esta vía de difusión ya que la iconografía la introduce en Valencia el Maestro de Bonifacio Ferrer cuya procedencia italiana es más que probable.

Tampoco puede descartarse completamente el papel del teatro como vía de transmisión del motivo. Aunque el tema no es demasiado frecuente en los Misterios, existe una referencia concreta de la aparición del Niño en escena descendiendo desde lo alto. La referencia aparece en una de las piezas del Ludus Coventriae (Salutation and Conception), bajo la forma de una rúbrica con indicaciones para la representación en la que se especifica:

"Here the holy gost discendit with III beyms to our lady: the sone of the godhead nest with III beyms. to the holy gost. the fadyr godly with III beyms to the sone, And so entre All ther to here bosom" ${ }^{88}$.

La rúbrica es un añadido interpolado en 1468 y parece estar basada en el relato de las Meditationes vitae Christi, probablemente en la versión inglesa de Nicolas Love (The Mirrour of the Blessed Lyf of Jesu Christi, ca. 1410) ${ }^{89}$. Sin duda la ejecución de las indicaciones de la rúbrica haria necesaria la utilización de muñecos que descenderían con un sistema de cables y poleas desde las bóvedas de la iglesia lo que podría explicar la rigidez de muchos de los Niños, especialmente en las Anunciaciones de los retablos de alabastro ingleses ${ }^{90}$. Se ha señalado también la posibilidad de que los rayos de luz en los que el Niño desciende "nadando" en la mayoría de las Anunciaciones en las que aparece el motivo fuesen la representación pictórica de los cables que se utilizaban para hacer descender los muñecos, y lo mismo podría decirse de los casos en los que el Niño y

87 En total he catalogado 25.

a BLoCK (1922), pág. 107.

as Block (1922), pág. XXIII.

9. ANDERSON (1963), págs. 133-34. 
la Paloma aparecen rodeados por aureolas circulares, probablemente inspiradas en los discos de madera pintados que se hacían descender en las representaciones teatrales ${ }^{21}$. Otros elementos de posible origen teatral son las fístulas y cadenas por las que desciende el Niño en algunos casos ${ }^{92}$. Lo que no está claro, a falta de otras referencias, es si en este caso el arte se inspira en el teatro o a la inversa. En concreto para el motivo del Niño, la rúbrica en la que aparece descrito es contemporánea de las obras inglesas en las que aparece la iconografía, todas ellas datadas en la segunda mitad del siglo XV y la mayoría hacia $1500^{93}$.

\section{ITALIA}

Puede discutirse si Italia fue o no la cuna de la iconografía, pero sí fue desde luego el lugar en el que ésta alcanzó su máximo desarrollo. Italianos son la mayoría de los casos conservados ${ }^{94}$ y la influencia italiana es evidente en más de la mitad de los ejemplares no itálicos.

En Italia el motivo del Niño aparece en fecha temprana (el primer ejemplo es el Lignum vitae de Pacino di Buonaguida pintado en los primeros años del siglo XIV ${ }^{95}$ ). Sin embargo, si exceptuamos el caso dudoso de P. Lorenzetti ${ }^{96}$, no vuelve a aparecer hasta la década de 1360 . Después de Pacino, la siguiente obra con fecha conocida es la Anunciación de Lorenzo Veneciano (1371, cat. $\mathrm{n}^{\circ}$ 8) pero, de ser cierta la suposición de Testi ${ }^{97}$, éste habría conocido el motivo a través de la obra de Guariento ${ }^{98}$, cuya Anunciación (cat. $n^{-}$) habría que fechar hacia 1360, lo mismo que la sienesa atribuida a Bartolo di Fredi (cat. $n^{\circ} 3$ ). Una cronología similar cabe asignar a las Anunciaciones de Giovanni di Benedetto da Como en el Libro de Horas de Blanca de Saboya (cat. no 5 y $n^{\circ}$ 6).

Existe por tanto un lapso de 40 años entre las Anunciaciones de Pacino y Lorenzetti y las de Guariento, Bartolo di Fredi y Giovanni di Benedetto, demasiados para sostener una filiación directa. La obra de Pacino no tuvo continuidad en Florencia hasta principios del siglo xV (Anunciaciones de

\footnotetext{
91 LARSON (1959), págs. 165-66 y 172.

92. Vid. supra nota 22.

93 Vid. CHEETHAM (1984), pág. 163. En el caso de los alabastros, es conocida su frecuente inspiración en las representaciones teatrales (Vid. HILDBURG (1949).

94 Catálogo $n^{\circ} 1-n^{0} 35$.

95 Es un caso bastante atípico (vid. cat. $\mathrm{n}^{\circ}$ 1). La fecha exacta está sujeta a controversia; Robb lo data hacia 1310, Schiller hacia 1320, y Guldan en 1306.

${ }_{96}$ Vid. cat. $\mathrm{n}^{\circ} 2$.
} 
Giovanni dal Ponte (cat. $n^{\circ} 15, n^{\circ} 16$ y $n^{\circ}$ 17). En el Treccento, el motivo, todavía poco frecuente ${ }^{99}$, aparece sobre todo en obras norteñas, venecianas o saboyanas y no será hasta el Quatroccento cuando la iconografía se extienda por toda Italia implantándose en medios populares.

Por otra parte, en las primeras Anunciaciones de la Italia del Norte, como en las bohemias, predomina el tipo en el que Dios Padre sostiene al Niño entre sus brazos, frente al de Pacino, luego más popular, en el que desciende del cielo "nadando" entre rayos de luz, lo que supone un motivo más para dudar de la filiación florentina de las Anunciaciones norteñas.

\section{PAISES GERMÁNICOS}

Fuera de Italia, es Bohemia la zona en la que primero aparece el motivo del Niño, en fechas además ligeramente más tempranas que las de los ejemplos conservados de la Italia del Norte, en los que, sin embargo, parece que los artistas bohemios debieron inspirarse. El motivo aparece en Bohemia hacia 1355 en el campo de la miniatura, en obras como el Schlackenwerter Kodex (cat. no 37) o el Liber Viaticus de Johan von Neumarkt (cat. $n^{\circ} 38$ ) que presentan evidentes influencias italianas. Hay que suponer por tanto la existencia de algunos ejemplares italianos perdidos con uná cronología en torno a 1345-50, ya que el italianismo de estas primeras Anunciaciones con Niño bohemias invita a dudar de la posibilidad de una invención independiente partiendo de prototipos locales en los que el Niño aparecía por transparencia sobre el pecho de María (vid. cat. nº 36).

Hay sin embargo un elemento de la iconografía de probable origen bohemio: la cruz, ausente en los primeros ejemplos italianos, que aparece por primera vez en el Antifonario del convento de Vorau hacia $1360^{100}$.

Veinte años después de su aparición en Bohemia, la iconografía se introduce en Alemania, donde llegaria a hacerse muy popular. Su introductor fue probablemente el maestro Bertram (Retablo de Grabow ${ }^{101}$ ) cuyo

97 TESTI (1909), págs. 214 y 223.

9 G Guariento di Arpo tuvo probablemente una formación florentina (su obra aparece influida por Giotto). Está documentada su actividad en Padua (1338-65) y luego en Venecia donde se le relaciona con Lorenzo Veneziano. Robb, siguiendo a Testi, le atribuye el papel de nexo entre las Anunciaciones florentinas y las véneto-saboyanas.

9 De los 35 casos italianos catalogados sólo 10 corresponden al siglo XIV.

${ }_{100}$ Cat. $n^{\circ} 40$. Sobre el origen y significado de la cruz véase, más arriba, pág. 22 y ss.

$101 \quad c a .1379$, cat. $n^{0} 42$. La obra es de un indigenismo evidente pero no cabe dudar de la influencia del llamado "segundo estilo bohemio". 
taller adoptó el motivo del Niño con entusiasmo, utilizándolo en al menos cuatro de sus populares altares pintados realizados a finales del siglo XIV ${ }^{102}$. A lo largo del siglo siguiente la nueva imagen se extiende por el resto de los países germánicos. La encontramos en el Tirol ${ }^{103}$, en la Suiza germana ${ }^{104} y$ en Alsacia ${ }^{105}$, en obras de todo tipo pero frecuentemente de carácter popular, perviviendo durante el primer tercio del siglo XVI.

\section{PENÍSULA IBÉRICA}

En la península, el motivo aparece tempranamente en los países de la corona de Aragón en ambientes de clara influencia italiana, extendiéndose más tarde por Castilla, Andalucía y Galicia. La primera Anunciación hispana en la que aparece el motivo del Niño ${ }^{106}$ (la de Jaume Serra en el retablo del convento del Santo Sepulcro de Zaragoza) ofrece una cronología muy temprana (1361), aunque se trata de un tipo especial, quizá independiente de los modelos italianos, ya que el Niño no aparece completo, sino sólo su rostro, como un pequeño sol rodeado de rayos de luz (cat. 71). Hay que esperar hasta finales del siglo para volver a encontrar la iconografía, ahora ya plenamente desarrollada, que reaparece simultáneamente en Cataluña (Pere Serra ${ }^{107}$ ), en Maliorca (Maestro del Obispo Galiana ${ }^{108}$ ) y en Valencia (Maestro de Bonifacio Ferrer ${ }^{109}$ ), siempre en obras de clara influencia italiana ${ }^{110}$.

Pocos años más tarde el motivo aparece en Castilla, de nuevo en una obra italianizante, relacionada con Starnina ${ }^{111}$. Sin embargo en el área castellana la mayoría de los ejemplos posteriores, ya de bien entrado el $S$. $X V$, pertenecen a la corriente hispanoflamenca que apunta hacia Holanda como una segunda vía de entrada del motivo en la península. Influencias norteñas se detectan también en el único ejemplo andaluz que

\footnotetext{
Vid. cat. $n^{\circ} 43, n^{\circ} 46, n^{\circ} 47$ y $n^{\circ} 48$.

Fresco de la Catedral de Brixen, cat. $n^{0} 50$.

Tapiz del museo de Zurich, cat. $n^{2} 58$.

Cat. $n^{0} 53$ y $n^{\circ} 69$.

Exceptuando, naturalmente, los precedentes citados en la página 27, cuyo carácter es distinto. Cat. $n^{-} 72$ Anunciación de la Galería Brera.

Cat. $n^{\circ} 81$ Retablo de la Anunciación y los Santos Juanes.

109 Cat. $n^{\circ} 78$ Retablo de Bonifacio Ferrer.

110 El italianismo del tailer de los Serra es bien conocido lo mismo que el del Maestro del Obispo Galiana, evidentemente relacionado con ellos. En cuanto al Maestro de Bonifacio Ferrer, es probablemente un italiano e incluso se le ha identificado con Starnina (Pitarch).

111 Cat. $n^{\circ} 84$ Capilla de San Blas de la Catedral de Toledo.
} 
he podido localizar ${ }^{112}$, y en uno de los dos ejemplos gallegos (La Anunciación de Seteventos, cat. no 92). Más complicada resulta, por su carácter fuertemente popular, la filiación del otro caso gallego, excepcional, por otra parte, en varios aspectos ${ }^{113}$. También en Portugal aparece la iconografía aunque el único caso que conozco es probablemente una obra importada de Flandes ${ }^{114}$.

Aunque en la mayoría de los trabajos dedicados al estudio del motivo, obra de autores alemanes, ingleses e italianos, apenas se citan ejemplos peninsulares, en España la iconografía gozó de una notable popularidad perviviendo hasta fechas muy avanzadas (cinco de los doce ejemplares posteriores a 1500 que he podido catalogar son hispanos). En total son veintitres las Anunciaciones peninsulares en las que aparece el motivo del Niño, la mayoría de la segunda mitad del siglo XV ${ }^{115}$.

\section{PAISSES BAJOS}

Si exceptuamos la tapa de evangeliario del museo de Berlín (cat. $n^{\circ}$ 94), cuyo origen es dudoso y, en todo caso, habría que considerar como un precedente sin solución de continuidad, el primer ejemplo de la iconografía aparece en los Países Bajos hacia 1400, una fecha relativamente tardía en comparación con la de las primeras obras italianas, germánicas o españolas. Los primeros ejemplos son obras de las provincias del norte ${ }^{116}$, relacionadas con el arte alemán desde donde el motivo debió de llegar a Flandes. Parece, sin embargo, que no tuvo el mismo éxito que en otros lugares (sólo once casos) y a pesar de su utilización por el maestro de Flemalle ${ }^{117}$, tan influyente en otros aspectos, ninguno de los artistas de primera fila posteriores lo adoptó.

\section{FRANCIA}

El caso francés es uno de los más complicados a la hora de establecer el origen, la procedencia y la cronología de aparición del motivo. Para

\footnotetext{
:12 Cat. n 91 Anunciación del Museo de Bellas Artes de Sevilla (Alejo Fernández).

113 Vid. cat. no 93 Anunciación de la lglesia de Sta. Mariña Dozo (Cambados, Pontevedra).

114 Vid. cat. $n^{0} 97$ Lámina de bronce de Leça do Balio.

115 Véase la del Libro de Horas de Santa Clara de Bernat Martorrell (ca. 1440), Fig. 6.

116 Cat. no 96 Altar Brenken.

17 Cat. no 98 Retablo de Mérode. (Fig. 1, detalle).
} 


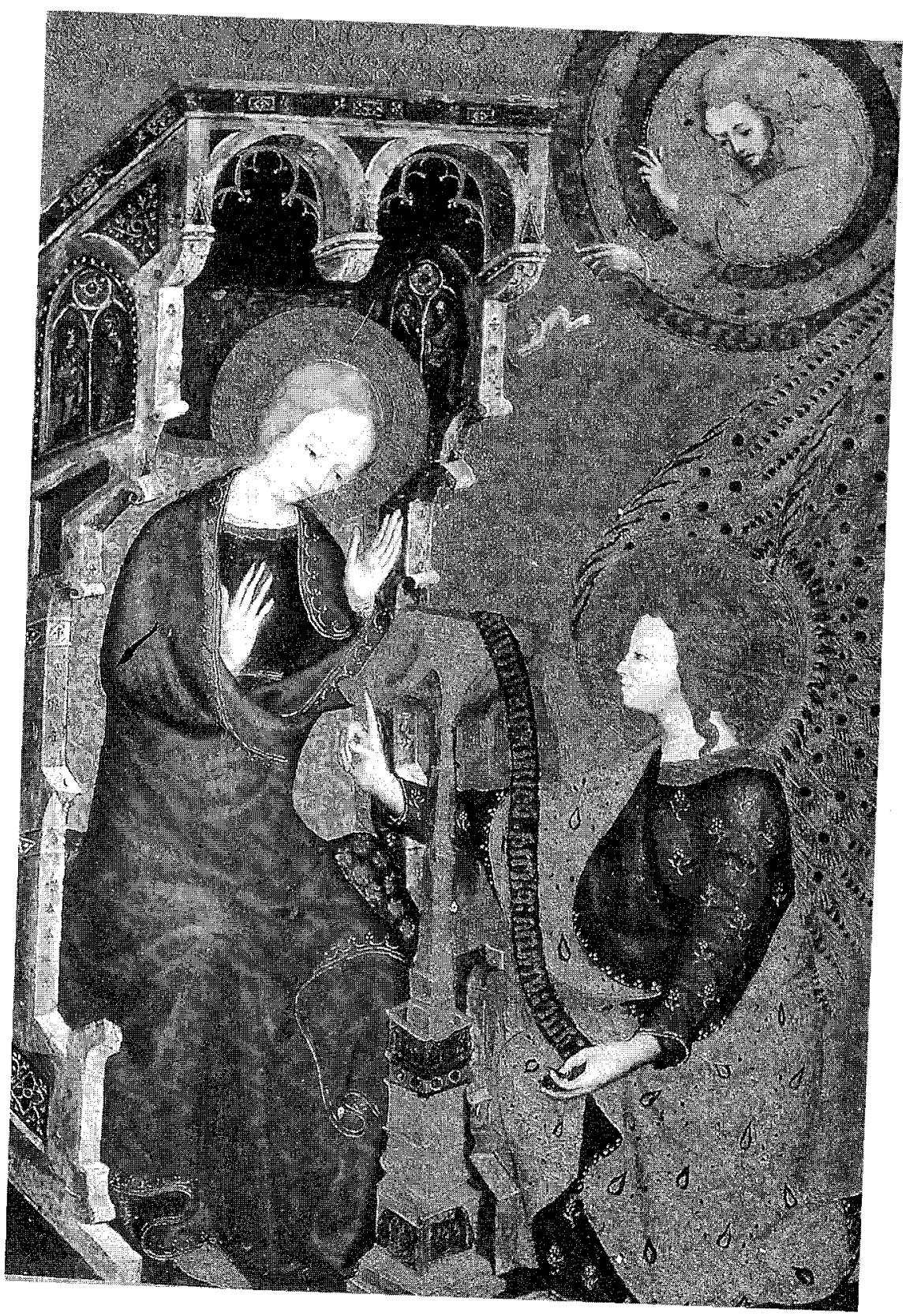

Fig. 4. Anunciación Sachs, ca. 1390, ¿Escuela de Avignon? 
Heimann, Francia sería la cuna de la iconografía, cuyo origen cree encontrar en las Biblias Moralizadas del siglo XIII ${ }^{118}$. Sin embargo, en la Francia del norte, donde fueron iluminadas las Biblias, el motivo del Niño no vuelve a aparecer en la Anunciación hasta el segundo cuarto del siglo xv, y su procedencia es, según todos los indicios, flamenca.

Contribuye a complicar el panorama la existencia de una obra ( $n^{\circ} 106$ Anunciación Sachs, Fig. 4) cuya cronología (ca. 1390) y la polémica sobre su procedencia dificultan la labor de trazar el cuadro de difusión del motivo. Generalmente se le atribuye a la italianizante escuela de Avignon lo que obliga a admitir una doble vía de penetración de la iconografía: procedencia flamenco-germana en las obras del norte e italiana en las de la escuela del Midi ${ }^{119}$. Sin embargo, no falta quien haya atribuido la Anunciación Sachs a la escuela de París ${ }^{120}$ e incluso quien, como Panofsky, dude del origen francés de la pieza, basándose precisamente en la presencia del Niño, desconocido en Francia en esos momentos ${ }^{121}$.

Los ejemplos conservados en Francia no son muy abundantes (11 casos incluyendo la Anunciación Sachs), cinco de ellos son miniaturas, cuatro tablas, una pintura al fresco y un tapiz. La primera obra de segura procedencia francesa en la que aparece el motivo es la Anunciación del Ms. 157 de la Biblioteca Morgan (cat. $n^{\circ} 107$ ), datado hacia 1430, que aúna influencias flamencas, italianas y locales en la línea del maestro de las horas de Boucciaut. Casi simultáneamente (ca. 1435) el motivo aparece en el Sur, en obras como la Anunciación avignonesa atribuida a Jacques Yverni, hoy en la National Gallery de Dublín (cat. nº 110).

\section{INGLATERRA}

Las Anunciaciones con Niño inglesas presentan particularidades que las independizan del resto de las del continente. En primer lugar sorprende lo tardio de su aparición - no hay ejemplos anteriores a 1450- y el hecho de que la mayoría de los casos sean retablos de alabastro atribuibles al taller

${ }_{119}^{19}$ Vid. supra pág. 24.

119 Ambas influencias se entrecruzan en obras como la Anunciación de Aix (cat. n² 111) o la de Lanslevillard (cat. $\mathrm{n}^{\mathrm{o}} 114$ ).

120 SteRling (1941), pág. 5 y (1987-90), vol. I pág. 15.

121 "The Parisien, even French, origin of the painting, which is hardly later than 1400, is all the more doubtful as the motif of the Christ Child bodily descending from Heaven was, at this time, as foreing to French art as it was popular in Italy and the Germanic countries". (PANOFSKY (1953), pág. 392). 
de Nottingham (siete de los diez casos catalogados). En casi todos ellos el Niño es de notables dimensiones y suele aparecer con los pies rozando la boca del Padre y la cabeza o las manos tocando la cabeza de María, resaltando que no se trata del embrión de Cristo sino del Logos, del Verbo divino.

Por otra parte, Inglaterra es el único lugar en el que puede suponerse razonablemente un origen independiente de los modelos italianos o bohemios. La existencia de un testimonio concluyente de que en las representaciones de los Misterios ingleses se utilizaban imágenes descendentes del Niño y de la Paloma, y la conocida inspiración de los alabastros ingleses en el teatro, autorizan a pensar en un origen teatral para la iconografía, 0 , al menos, en una influencia de las representaciones teatrales en la configuración del modelo inglés de Anunciación con Niño ${ }^{122}$.

\section{LAS CONDENAS}

Durante más de un centenar de años el motivo del Niño en la Anunciación se difundió por Europa sin encontrar oposición, apareciendo en todos los países y en todos los campos de la actividad artística sin que los teólogos encontrasen nada reprensible en la iconografía. La primera condena del motivo aparece hacia 1440-1454 en la obra de San Antonio de Florencia, para el cual la presencia del Niño descendiendo del cielo completamente formado podría llevar a pensar que su cuerpo no se hubiera constituido a partir de la substancia materna ${ }^{123}$.

Se ha supuesto que la condena del dominico florentino tuviera su explicación en el hecho de que el motivo del Niño tiene su origen en ambientes franciscanos con lo que el rechazo de San Antonino no sería más que un episodio de la conocida rivalidad entre ambas ordenes ${ }^{124}$. Sin embargo, el problema no es tan sencillo. Es cierto, como hemos visto, que la imagen es la expresión de la mística franciscana pero frente a lo que

122 Sobre este aspecto véase más arriba la página 32.

${ }^{23}$ San Antonio de Florencia, Summa Theologica, III, tit. 8, 4, 11.

"Reprehensibiles, inquit, sunt etiam Pictores, cum pingunt ea quae sunt contra fidem: cum faciunt Trinitatis Imaginem unam personam cum tribus capitibus; quod monstrum est in rerum naturam: vel, in Annunciationis parvulum Puerum formatum, scilicet lesum mitti in uterum Virginis, quasi non esset de sunstantiam Virginis corpus ejus assumptum: vel parvulum Jesum cum tabulam litterarum, cum non didicerit ab nomine...".

La cita deja claro que el problema no es el motivo en sí, sino la confusión que puede producir cuando se utiliza en la escena de la Anunciación, de ahi que las condenas nunca se hicieran extensivas a las adaptaciones que se hicieron de la iconografía (vid. supra nota 34 ).

${ }_{124}$ LIPINSKY (1954), pág. 260. 


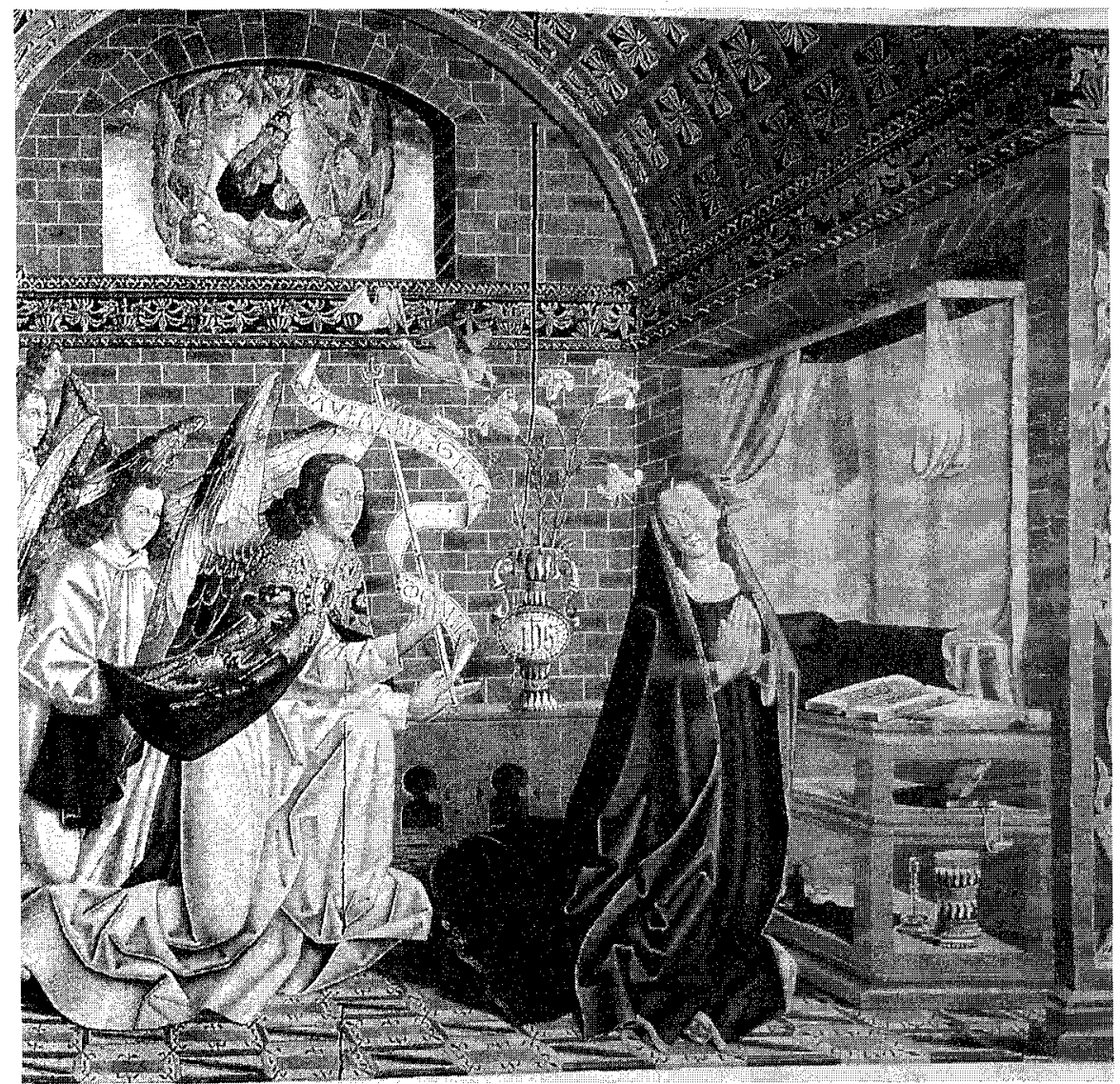

Fig. 5. Alonso de Sedano, Anunciación del Armario de las Reliquias de la Catedral de Burgos, ca. 1495.

pudiera parecer, en la mayoría de los ejemplos tempranos de la iconografía aparecen, de una u otra forma, referencias a la orden dominica ${ }^{125}$. Las razones del rechazo hay que buscarlas en la personalidad del propio $\mathrm{S}$. Antonino, celoso defensor de la ortodoxia en los turbulentos días del cisma (antes de ser nombrado arzobispo de Florencia ocupó el cargo de vicario de la Observancia para toda Italia), y en su intenso afán de dirigir espiritualmente no sólo a los monjes de su orden sin todas las actividades de la ciudad: la economía, el arte, la vida en suma. Por otra parte, la condena

125 Rовв (1936), pág. 524 nota 157. 
de las Anunciaciones con Niño no aparece en la obra del florentino como un hecho aislado sino unida al rechazo de otras muchas imágenes que él considera ridículas, apócrifas o monstruosas: las Trinidades trifrontes y trifaciales, los desnudos, las parteras en la Natividad... San Antonino es simplemente un retrógrado opuesto a cualquier originalidad y novedad y preocupado de someter a los artistas al criterio de los teólogos ${ }^{126}$.

La condena de San Antonino por tanto hay que entenderla al margen de las disputas entre los mendicantes y cobra sentido frente a la opinión de quienes, como el cardenal Hugo de Saint-Cher (ca. 1200-63), sostenían que el cuerpo de Cristo había sido enviado desde el cielo ya formado. (vid. supra nota 33 ).

Los argumentos de San Antonino los recogen más tarde los teólogos postridentinos, especialmente Molanus de Lovaina ${ }^{127}$, intérprete de las ideas emanadas de Trento, al considerar a la imagen contaminada de la herejía valentiniana que postulaba que el cuerpo de Cristo había sido enviado del cielo ya formado, entrando en la Virgen tanquam per fistulan transisse ${ }^{128}$.

Si la autoridad de San Antonino no fue suficiente para desterrar el motivo -todavía en la segunda mitad del XV son abundantes los ejemplos de

126 Sobre la figura de San Antonino el estudio más completo sigue siendo el de MorÇAY (1914) a quien sigue básicamente D'ADDARIO (1961). Sobre su actividad como mentor iconográfico de Fra Angelico, Fra Benedetto y otros artistas florentinos véase CREIGHTON (1959) que destaca su consideración de la pintura como un arte liberal. De la influencia de la Summa en el arte se ha ocupado Frederick Hartt en varios de sus trabajos y, recientemente, ScotTı (1983).

${ }_{127}$ Molanus de Lovaina, De historia sanctorum imaginum et picturarum, pro vero earum usu contra abusus libri quatuor, (Libro II, cap. XXIII "Observatio circa historiam Annunciationis Dominicae". (Ed. de J.N. Paquot, Lovaina, 1771, págs. 70-71). (1aㅡ ed. (De picturis et imaginibus sacris), Lovaina, 1570, fols. 39v-40r; ed. ampliada, Lovaina, 1594, fols. 121v-122v).

"Pingitur enim quibusdam locis, in historiam Annunciationis et Incarnationis Dominicae, Corpusculum quoddam humanum inter radios, quos Spiritus Sanctus diffundit, descendes ad uterum beatissimae Virginis, quae Pictura videtur praebere occasionem erroris, non solum periculosi, sed etiam haeretici. Valentinus enim ab antiquo haereticus est habitus Ecclesiam, quia docuit Christum corpus de coelo attulise, et per Mariam tantum tanquam per fistulan transisse. Unde Sanctus Antoninus hanc Picturam acriter reprehendit:". (sigue la cita literal de San Antonio de Florencia).

128 Puede parecer extraña la alusión a Valentino, un filósofo del siglo Il cuyas doctrinas gnósticas sólo eran conocidas por las condenas de San Ireneo y Tertuliano. Sin embargo, en los siglos XIV y XV coexistían todavía opiniones dispares con respecto al misterio de la Encarnación (vid. supra nota 33), lo que puso de nuevo de actualidad las ideas de Valentino. A la herejía valentiniana se refiere probablemente también el maestro Johannes Eckhardt —él mismo sospechoso de herejía- cuando escribe, a comienzos del siglo xIv: «..secundum haereticorum dogma verbum assumpise caeleste corpus aliquod, non humanum, sed ideo dicitur de caelo descendere, quia non ex virili semine, ut alii dicunt haeretici, sed mystico spiramine verbum Dei factum est caro, secundum illud Luc. 1: "Spiritus Sanctus superveniet in te». (Gossman (1957), pág. 211, nota 12). 
la iconografía, algunos en la misma Florencia-, la condena de Trento ${ }^{129}$ difundida en el tratado de Molanus sí resultó decisiva. Sólo dos casos (E) Retablo de Montesión (cat. no 82) y la Anunciación de F. Segala (cat. $n^{\circ}$ 35) son posteriores a las resoluciones del concilio. No obstante conviene no sobrevalorar la influencia de las condenas mencionadas que se limitaron a certificar la defunción de una imagen que ya hacía algún tiempo que había dejado de utilizarse. Salvo las excepciones señaladas el motivo desaparece hacia $1525-30$ y los ejemplares cuya cronología rebasa el 1500 son escasos y pertenecientes todos a ambientes "populares", retardarios en iconografía y estilo.

Sin embargo, la desaparición de la imagen no supone el fin de las condenas, convertidas ya en un tópico para quienes pretendían definir la ortodoxia del arte católico. Todavía en el XVII, cuando en el arte el motivo había caído completamente en desuso, el eco de las condenas de San Antonino y Molanus resuena en la obra del iconógrafo y pintor sevillano Francisco Pacheco ${ }^{130}$, y, ya en el XVIII, en la del mercedario español Interián de Ayal ${ }^{131}$. Ambos recurren a las citas del arzobispo florentino y a

129 El decreto del Concilio de Trento sobre las imágenes (3-4 diciembre 1563) se limita a dar unas indicaciones generales sobre la finalidad de las imágenes y el uso legítimo que puede hacerse cué éstas, sin ocuparse de casos concretos. No obstante, a partir de lo que se estipula en el decreto ("que no se coloquen imágenes algunas de falsos dogmas, ni que den ocasión á los rudos de peligrosos errores"), los concilios provinciales y sucesivas generaciones de teólogos (Molanus, Paleotti, Bellarmino...) fueron concretando las imágenes susceptibles de inducir al error, como es el caso de la que nos ocupa. Sobre la influencia de Trento en el arte pueden consultarse los trabajos clásicos de DEJOB (1884) y MẢLE (1932), que coinciden en asignar a las disposiciones del Concilio un papel fundamental en la renovación de la iconografia. Posturas más recientes que tienden a minimizar o relativizar su influencia son las que mantienen FRANCASTEL (1970) y BLUNT (1964). El texto de las disposiciones conciliares, abundantemente citado, puede consultarse en edición bilingüe en LÓPEZ DE AYALA (1798), págs. 355-60, y la mayoría de los tratados inspirados por éstas en BAROCCH (1960). Para lo relativo a la influencia del decreto en la Península véanse: Hornedo (1945); Saravia (1960); Cañedo-Argüelles (1974) y (1982); PINTo CRESPO (1978-79) y RODRÍGUEZ GUTIÉRREZ (1984).

13) Francisco Pacheco, Arte de la Pintura (ca. 1638), cap. XII, «Pintura de la Anunciación de nuestia Señora» (Ed. de B. Bassegoda i Hugas, Madrid, Cátedra, 1990, pág. 595).

«...la cual pintura, no sólo es ocasión de error, peligroso, pero herético, como advirtió Molano, porque se conforma con el parecer de Valentino y sus secuaces a quien la Iglesia santa ha muchos que condenó por hereje, porque enseñó que Cristo, nuestro Señor, traxo el cuerpo del cielo, y, por esto, San Antonino reprehende con rigor esta pintura, porque es de te que el Espíritu Santo formó el cuerpo de Cristo nuestro Señor de la sustancia de la sacratísima Virgen, en sus purísimas entrañas".

${ }_{131}$ Fr. Juan INTERIAN DE AYALA, El pintor christiano, y erudito ó tratado de los errores que suelen cometerse frecuentemente en pintar, y esculpir las Imágenes Sagradas. 8 Libs. 2 vols., Madrid, Imp. de Joachin lbarra, 1782.

"Y lo que vemos algunas veces en la historia de la Anunciación de la Virgen, y de la Encarnación del Señor (lo que hago memoria de haber advertido en algun Breviario), sin duda es yerro, ó á lo 


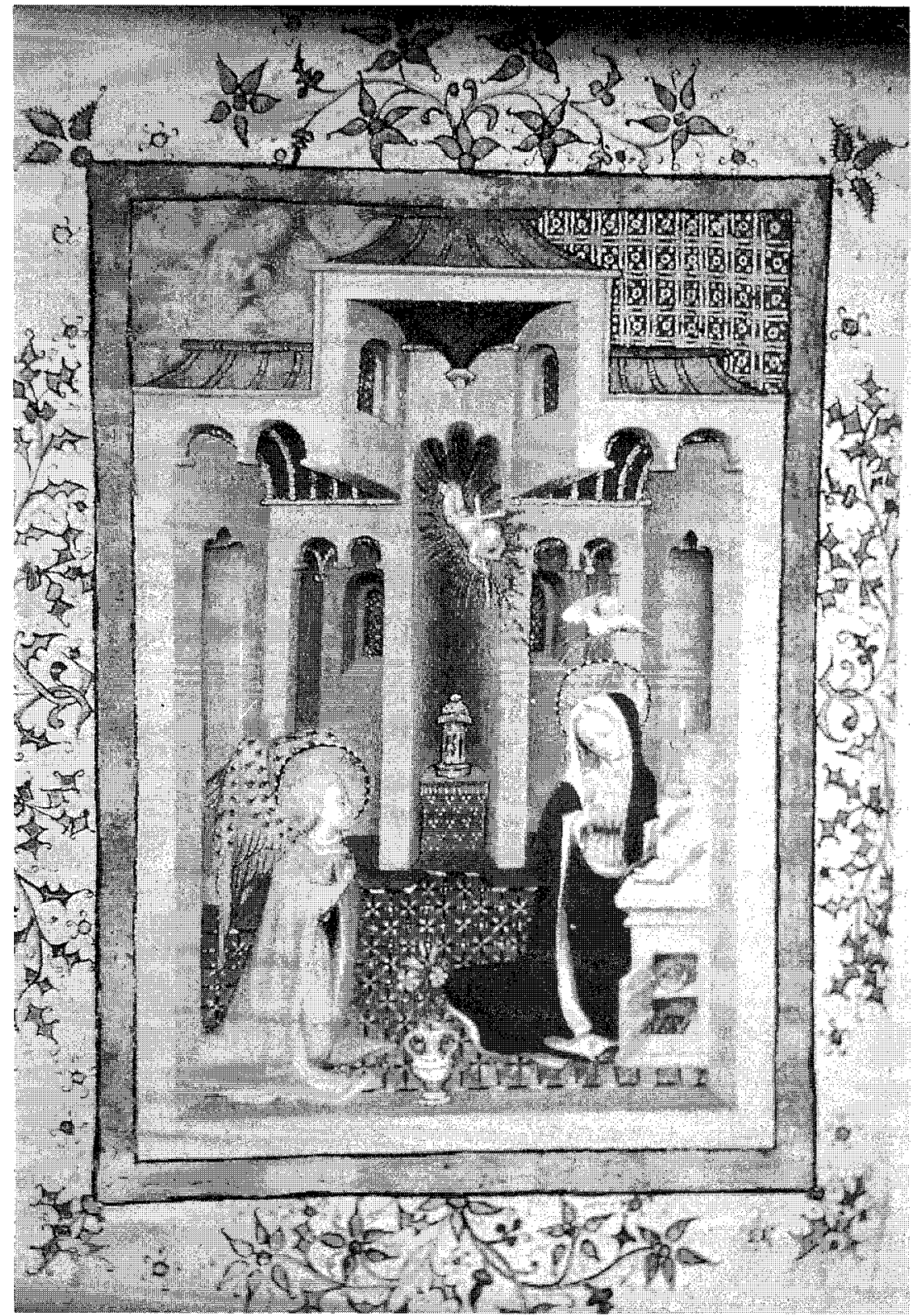

Fig. 6. Bernat Martorell, Libro de Horas de Sta. Clara, ca. 1440. 
la autoridad de Molanus y reiteran las acusaciones de valentinianismo y de inducción al error para justificar su rechazo hacia el motivo. Ayala, cuya obra ejerció una notable influencia ${ }^{132}$, califica a las obras en las que aparece como «rudas y ridículas», epítetos convertidos en tópicos en todas las referencias al motivo de los siglos XVII y XVIII ${ }^{133}$.

La nómina de sanciones contra el motivo culminaría, según algunos autores, con la condena ex cathedra de Benedicto XIV en el siglo XVIII ${ }^{134}$. No he podido encontrar, sin embargo, la menor referencia al motivo que nos ocupa en las obras del Papa Lambertini. Entre los que se refieren a la supuesta condena papal el único que cita la referencia concreta es Lipinsky pero la carta papal a la que se remite ${ }^{135}$, en la que Benedicto XIV condena las Trinidades tricéfalas y trifaciales, no hace referencia al motivo del Niño en la Anunciación sino a las imágenes de la Virgen que muestran la Trinidad en su interior (las «Abrideras») ${ }^{136}$, y es significativo que en el mencionado escrito, en el que se cita constantemente a San Antonino, Molanus e Interián de Ayala, se omita la condena al motivo del Niño y se interrumpa la cita de San Antonino -quien condena conjuntamente la Trinidad trifronte y la Anunciación con Niño- precisamente cuando éste

menos una pintura que dá ocasión a fatales, y perniciosos errores. Pues en ella, entre los rayos de luz que baxan desde el Cielo á la tierra, y hasta la misma Virgen, se ve pintado un cuerpecillo bien organizado, aunque pequeño, el cual baxa al sagrado vientre de la Virgen. ¿Y quién, por medianamente que esté instruido dexará de conocer que esta pintura abriga el herético error de Valentino, ó por lo menos, que dá manifiesta ocasión de semejante gravedad? [...] Por esto reprende y condena con razón esta pintura San Antonino, como que abre el camino para la herejía» (Lib. I, cap. VII, nº 3, págs. 56-57).

${ }_{132}$ El original fue publicado en latín (Pictor Christianus, Madrid, 1730) pero pronto se hicieron traducciones (la castellana citada de Fr. Luís de Durán y de Basteró) y ediciones revisadas y resumidas como la de Luigi Napoleone Citadella, Istruzioni al Pittor Cristiano, Ferrara, 1854. Su obra influyó también en Benedicto XIV que le cita frecuentemente en términos elogiosos y sigue al pie de la letra sus ideas en materia de iconografía, remitiéndose a su autoridad cuando se plantean dudas sobre la licitud de alguna imagen.

${ }_{133}$ Véanse los juicios de Pierre-Joseph de Haitze (1679) y de Fauris de Saint-Vincens (1790) sobre la Anunciación de Aix, en los que se prodigan los calificativos de «grotesco", "ridículo" etc., en referencia al motivo del Niño (BOYER (1959), págs. 302-303).

${ }_{134}$ KünSTLE (1926), I, pág. 340; JEG!-OT (1927) pág. 56; RoBB (1936), pág. 526; LIFINSKY (1954), pág. 264, nota 15; Silva Maroto (1995), pág. 58.

135 Literae Apostolicae ad Episcopum Augustanum (Solicitudine Nostrae, 1-Oct-1745), aparece recogida en su Opera Omnia (Roma, Imp. Palearini, 1751) dentro del tratado Acta et Decreta in causis Beatificationum et Canonizationum, vol. VI, cap. XII, y en el Bullarium, Venecia, Imp. de Joannis Gatti, 1778, págs. 250-255.

${ }_{136}$ "Inter reprobatas Imagines Sanctissimae Trinitatis ea procul dubio recesenda est, quam pluribus infectantur Joannes Gerson [...] ubi nimirum repraesentabatur Dei para Virgo Trinitatem ipsam in utero gerens, quasi vero tota Trinitas humanam carnem ex Virgine Assumpisisset". Benedicto XIV. Op. cit. $\$ 27$.

${ }_{137}$ Como señalan Boespflug y Besançon, Benedicto XIV en sus propuestas sobre las imágenes, que en muchos casos habría que calificar de iconoclastas, evita tocar el centro de ta teología 
pasa a condenar el motivo que nos ocupa ${ }^{137}$. Tampoco se refiere al motivo en su tratado De sacris imaginibus et nonnulius controversiis ad eas pertinentibus ${ }^{138}$, en el que comenta las disposiciones de Trento y pasa revista a las imágenes lícitas y reprobables, ni en el capítulo que dedica a la Anunciación en su De Festis ${ }^{139}$.

En todo caso, la condena, de existir, tan sólo tendría el valor de un tópico literario-teológico sin que pueda pensarse en una pervivencia del motivo hasta fechas tan avanzadas. Seguían existiendo naturalmente, a pesar de las condenas y de las propuestas iconoclastas de Ayala ${ }^{140}$, obras antiguas en las que aparecía el motivo -especialmente abundantes en Italia y los Países Germánicos- y ello explica que todavía a principios del siglo XIX la célebre estigmatizada alemana Katharina Emmerich (1774-1824) en sus visiones, transcritas en 1818 por Clemente Brentano, describa a María, tras la partida de Gabriel, en los siguientes términos: "La Virgen adoraba la Encarnación del Salvador, que se había encarnado en ella como un pequeño cuerpo humano completamente formado" ${ }^{141}$.

de la imagen, que es, en realidad, la Encarnación. (Vid. BoEspflug (1984), pág. 259. Y BESANĢON (1994), pág. 242).

${ }_{138}$ Opera, vol. IV, cap. XXI, págs. 761 ss., Roma, Imp. Palearini, 1751.

139 De Festis Domine nostri Jesu Christi et Beatae Mariae Virginis, Opera, vol. X. Lib. II cap. III. De festo Sanctissimae Annunciationis. Die 25. Marti, Roma, Imp. Palearini, 1751, págs. 443 ss.

140 «Baste advertir que estas pinturas, é Imágenes, deben omitirse enteramente, y aún (según yo pienso) deben borrarse, ó quitarse, si todavia ha quedado alguna de ellas. Porque, si bien podrian interpretarse en otros sentidos píos, como observó un teólogo que escribió sobre estas materias [se refiere a Molanus, lib. 3, cap. 13]; sin embargo no veo por que deba hacerse tanto caso de dichas Pinturas (que por lo menos son rudas, y ridículas), que por ellas se haya de recurrir á un sentido muy remoto, y escondido." (Interián de Ayala, Op. cit., lib. IV, cap IV, nº 2, págs. 27-28).

No conozco ningún caso documentado que haya sido voluntariamente destruido aunque si hay constancia de algunas obras en las que aparecia el motivo que hoy han desaparecido (vid. cat. $n^{\circ}$ 73 y $\left.n^{\circ} 77\right)$. Especialmente significativo es el caso del retablo de Lluís Borrasá en la iglesia de Sta. $M^{a}$ de Copons (cat. $n^{0} 73$ ) el cual se conserva completo excepto la tabla de la Anunciación, sustituida por una escultura.

141 Reau (1955-59), II, II, pág. 193. 


\section{BIBLIOGRAFIA}

ANDERSON, Mary Desirée: Drama and Imagery in English Medieval Churches, Cambridge, University Press, 1963.

BARocChI, Paola: Trattati d'arte del Cinquecento fra Manierismo e Controriforma, Bari, 1960.

BeISSEL, Etienne S. J.: «Un livre d'heures appartenant a S. A. le duc d'Arenberg à Bruxelles", Revue de l'art chrétien, XLVII (1904), pp. 437-47.

BESANÇON, Alain: L'image interdite. Une historie intelectuelle de l'iconoclasme, París, Fayard, 1994.

BLock, K. S. (Ed.): Ludus Conventriae or the Plaie called Corpus Christi, Oxford, Early English Text Society, E. S. ํㅜ 120, 1922 (Krauss reprint 1974).

BLunt, Anthony: Artistic theory in Italy 1450-1600, Oxford, 1964 (Hay trad. castellana, Madrid, Cátedra, 1979).

Boespflug, François: Dieu dans l'art, París, Ed. du Cerf, 1984.

BorD, B.: "Les grossesses à enfant visible dans l'art chrétien», Aesculape, 23 (1933), pp. 81 ss. y 105 ss.

BOYER, Jean: «Documents inédits sur le triptyque de l'Annonciation d'Aix», Gazette des Beaux Arts, LIV (1959), pp.301 ss.

CABROL, F. y LECRECQ, J.: Diccionnaire de Archéologie Chrétien et de Liturgie, París, 1926.

CAÑEdo-Argüelles, C.: «La influencia de las normas artísticas de Trento en los tratadistas españoles», Revista de ldeas Estéticas, 127, pp. 223-42.

Cañedo-Argüelles, C.: Arte y teoría: la Contrarreforma y España, Oviedo, Ethos Arte, Pub. Universidad de Oviedo, 1982.

CREIGHTON, Gilbert: "The Archbishop on the Painters of Florence, 1450", Art Bulletin, XLL, 1 (1959), pp. 75-87. 
CHEETHAM, Francis: English Medieval Alabasters with a Catalogue of the Collection in the Victoria and Albert Museum, Oxford, PhaidonChristie's, 1984.

D'ADdARIO, A.: "Antonino Pierozzi», Dizionario Biografico degli italiani, Roma, 1961, vol. 3, pp. 524 ss.

D'Ancona, P.: Origine del teatro italiano, Turín, 1891.

De BARTHOlomaeis: Le Origini della poesia drammatica italiana, Bolonia, 1924.

DeJob, Ch.: De l'influence du Concile de Trente sur la litterature et les beaux-arts chez les peuples catholiques, París, Ernst Thorin, 1884.

Delclaux, Federico: Imágenes de la Virgen en los códices medievales de España, Madrid, Patronato Nacional de Museos, 1973.

DENNY, Don: The Annunciation from the Right, from Early Christian Times to the Sixteenth Century, Nueva York, Garland, 1977.

Doglıo, F.: Teatro in Europa. Storia e documenti I, Milán, 1982.

DubreulL, Mathieu H.: Valencia y el Gótico Internacional (2 vols.), Valencia, Institut Alfons el Mlagnanim, 1987.

EDGERTON, S. Y.: «Merisurare temporalia facit Geometria spiritualis. Some 15th-century Italian notions about when and where the Annunciatin happened", Studies in late Medieval and Renaissance Painting in Honor of Millar Meiss, Nueva York, 1977, pp. 115 ss.

EDMUNDS, Sheila: «The Missals of Felix $V$ and Early Savoyard Illumination», Art Bulletin, XLVI (1964), pp. 127-141.

FEudALE, C.: «The iconography of the Madonna del Parto», Marsyas, 7 (1957), pp. 8 ss.

FOURNEE, Jean: «Architectures symboliques dans le théme iconographique de l'annonciation", Syntronon. Art et archéologie de la fin de l'antiquité et du Moyen âge, París, 1968, pp. 225-35.

FRANCASTEL, Pierre: La realidad figurativa. Elementos estructurales de sociología del arte, Emecé, Buenos Aires, 1970.

GARCIA IGLESIAS, José Manuel: La pintura manierista en Galicia, Fundación Barrié de la Maza, La Coruña, 1986.

GILLET, L.: Historie artistique des ordes mendiants, París, 1912.

GolDSCHMIDT, Adolf: Die Elefenbeinskulpturen aus der Zeit der karolingischen und sächsischen Kaiser VIII-XI. Jahthundert, Berlín, 1914-26. (Reprint 1970). 
GONZÁlez MonTAÑÉs, Julio I.: «Parvulus puer in annuntiatione virginis. Los relieves de Santa Mariña Dozo», Archivo Español de Arte, 266 (1994), pp. 68-71.

Gössmann, M. Elisabeth: Die Verkündigung an Maria im dogmatischen Verständnis des Mittelalters, Munich, M. Hueber, 1957.

GotTLIEB, Carla: «A Sienese Annunciation and its fenestra Cancellata», Gazette des BeauX Arts, LXXXIII (1974), pp. 89-96.

Grimoüard dE SAINT-LAURENT, H. L., comte de: Guide de l'art chretien; etudes d'esthetique et d'iconographie, París, Librairie archeologique de Didron, 1872-74.

GuerRA, Manuel: Simbología románica, Fundación Universitaria Española, Madrid, 1978.

GULDAN, Ernst: «Et Verbum caro factum est». Die Darstellung der Inkarnation Christi im Verkündigungsbild», Römische Quartalschirift für christliche Alterumskunde und Kirchengeschichte, 63, 3-4 (1968), pp. 145-69.

GuLdan, Ernst: Eva und Maria. Eine Antithese als Blidmotiv, Graz-Köln, 1966.

HaUssherR, Reiner: Biblia moralizada de Viena, Madrid, Casariego, 1992.

HeImann, Adelheid: «Trinitas Creator Mundi», Journal of the Warburg and Courtauld Institutes, II (1938-39), pp. 42-53.

HILDBURG, W. L.: «English Alabasters Carvings as Records of Medieval Religious Drama», Archaeología, XCIII (1949), pp. 51-101.

HIRN, Yrjö: The Sacred Shrine, Londres, 1912.

HORnEDO, R.: «Arte Tridentino», Revista de Ideas Estéticas, 12 (1945), pp. 203-32.

HORTON: The Child Jesus, Londres, 1975.

IBAÑEz, J. y Mendoza, F.: María en la liturgia hispana, Pamplona, Eunsa, 1975.

JeGlot, C.: La Vie de la Vierge dans l'art, Paris, 1927.

KANE, Eileen: "A Fifteenth Century Avignonese Annunciation in Dublin», Gazette des Beaux Arts, LXXXIII (1974), pp. 193-204.

KüNSTLE, Karl: Ikonographie der christlichen Kunst, Friburgo, 1926-1928 (2 vols.).

LABORDE, Comte Alexandre de: La Bible Moralisée conservée a Oxford, Paris et Londres, París, 1911-27, 5 v. 
LARSON, Orville K.: "Ascension images in art and theatre", Gazette des Beaux Arts, 54 (1959), pp. 161-176.

Leroquals, V., Abbe: Le Bréviarie de Philippe le Bon, breviaire parisien du $X V e$ siècle..., Paris-Bruxelles-New York, M. Rousseau/Ch. Weckesser/ G.E. Stecher, 1929.

LIPINSKY, Angelo: "Contributi all'iconografia dell'Annunciazione: "Et Verbum caro factum est"», Arte Cristiana, Milán, 41 (1954), p. 260 ss.

LIPINSKY, Angelo: "Heterodoxe Darstellungen der Verkuendigung Mariae», Das Muenster, 11 (1958b), pp. 250-52.

LóPEZ DE AyALA, Ignacio: El Sacrosanto y Ecuménico Concilio de Trento traducido al idioma castellano por Ignacio López de Ayala, Madrid, Imprenta Real, 1875 (2ª Ed.).

Llompart Moragues, Gabriel: «A propósito de unas tablas medievales mallorquinas de la Anunciación y su ambigüedad iconográfica», Boletín del Seminario de Estudios de arte y Arqueología de la Universidad de Valladolid, 30 (1964), pp. 185-196.

MÂLE, Emile: "Le renouvellement de l'art par les "Mystères" à la fin du moyen âge", Gazette des Beaux Arts, 31 (1904), pp. 89-106, 215-230, 283-301 y 379-394.

MÂLE, Emile: El arte religioso del siglo xii al xviii, Madrid-Buenos Aires, Fondo de Cultura Económica, Breviarios no $59,1952$.

MÂLE, Emile, El Gótico: La iconografía de la Edad Media y sus fuentes, Madrid, Encuentro, 1986.

MÂLE, Emile: L'art religieux de la fin du Moyen Age en France, París, Armand Colin, 1922 (2ª Ed., 1ª 1908).

MATEO GÓmEZ, Isabel: «Temas paganos cristianizados», VI Jornadas del departamento de $H^{a}$ del arte "Diego Velázquez": La visión del mundo clásico en el arte español, Madrid, Editorial Alpuerto-CSIC, 1993, pp. 37-48.

MoRALEJo ÁlVAREZ, Serafín: «Aportaciones a la interpretación del programa iconográfico de la catedral de Jaca», Homenaje a $D$. José $M^{a}$ Lacarra de Miguel, Zaragoza, 1977, l, p. 173-202.

Morçay, R.: Saint-Antonin, archevêque de Florence (1389-1459), París, 1914.

Oliger, P. L.: «Le Meditationes vitae Christi del Pseudo-Bonaventura», Studi francescani, VII (1921), pp. 143 ss. y (1922), pp. 18 ss. 
Orlandi, S.: Bibliografía Antoniniana, Roma, 1962.

PANOFSKy, Erwin: Early Netherlanding Painting, Cambridge, Mass. 1953.

PINTO CRESPO, V.: «La actitud de la Inquisición ante la iconografía religiosa. Tres ejemplos de su actuación», Hispania Sacra, XXXI (1978-79), pp. 285-322.

REAU, Louis: Iconographie de l'art chretien, París, 1955-59 (6 vols.).

RoBB, David M.: "The Iconography of the Annunciation in the Fourteenth and Fifteenth Centuries", Art Bulletin, XVIII (1936), pp. 480-526.

Rodríguez Gutiérrez, A.: “La repercusión en España del decreto del Concilio de Trento acerca de las imágenes sagradas y las censuras al Greco", Studies in the History of Art, 1984, vol. 13, pp. 153-58.

Rosenau, Helen: "A Study in the Iconography of the Incarnation", Burlington Magazine for Connoisseurs, 85 (1944), pp. 176-79.

San Antonio de Florencia: Summa Theologica, Verona, Typ. Seminarii, apud Agostinum Carattonium, 1740. (Hay ed. facsímil de J. Colosio O. P., Graz, 1959).

Santos Otero, Aureliano de: Los Evangelios Apócrifos, Madrid, B.A.C., $1975\left(3^{a}\right)$.

SaRaviA, C.: «Repercusión en España del decreto del Concilio de Trento sobre las imágenes", Boletín del Seminario de Estudios de Arte y Arqueología de Valladolid, t. XXVI (1960), 129-43.

ScotTI, Giuseppina: «Alcune ipotesi di lettura per gli affreschi della Capella Portinari alla luce degli scritti di S. Antonino vescovo di Firenze», Arte Lombarda, 64 (1983), pp. 65-78.

SCHAPIRO, Meyer: "Muscipula Diaboli», the Symbolism of the Mérode Altarpiece", Art Bulletin (1945), pp. 182-187.

SCHILLER, Gertrud: Iconography of Christian Art, Londres, Land Humphries, 1971-71.

Silva Maroto, Ma del Pilar: Pintura hispanoflamenca castellana. Burgos y Palencia, Valladolid, Junta de Castilla y León, 1990.

Silva Maroto, Pilar: "Pinturas del Armario de las Reliquias», en Catálogo de la Exposición «Tesoros de la Catedral de Burgos». El arte al servicio del culto, Madrid, Banco Bilbao Vizcaya, 1995, pp. 56-75.

Simı VARANelL, Emma: "Las Meditationes Vitae Nostri Domini Jesu Christi Nell'Arte del Duecento italiano", Arte Medievale, 2 (1992), 137-48.

SPENCER, J. R.: "Spatial Imagery of the Annunciation in Fifteenth Century Florence», Art Bulletin, 37 (1955), pp. 273-80. 
Stalling, J. M.: Meditationes de pasione Christi olim Sancto Bonaventurae attributae, Washington, 1963.

SteInBeRg, S. H.: "Abendländische Darstellungen der Maria Platytera», Zeitschrift für Kirchengeschichte, 51 (1932), pp. 512 ss.

Sterling, Charles (con el seudónimo de Ch. Jacques): Les Peintres du Moyen Âge, París, 1941.

SteRling, Charles: La pinture medievale à Paris 1300-1500, París, Bibliotèque des Artes, 1987-1990 (2 vols.).

TESTI, L.: La Storia dellal pittura veneziana, Bérgamo, 1909.

THODE, J.: Franz von Assisi und die Anfäge der Kunst der Renaissance in Italien, Berlín, 1885. (Hay traducción francesa por Gaston Lefevre, París, Libr. Renouard 1909, 2 v.).

TOLnAY, Charles: «L'autel Merode du maitre de Flémalle», Gazette des Beaux Arts, LIII (1959), pp. 65-77.

VERHEYEN, Egon: "An iconographic note on Altdorfer's "Visitation" in the Cleveland Museum of Art», Art Bulletin, 46 (1964), pp. 536-38. 
